\title{
"Music is Music": Anton Ivanovich is Upset (1941) and Soviet Musical Politics
}

\author{
PETER KUPFER
}

\begin{abstract}
In this article I analyze the musical politics of the 1941 Soviet film Anton Ivanovich serditsya (Anton Ivanovich Is Upset), directed by Aleksandr Ivanovsky, original score by Dmitry Kabalevsky. The film tells the story of the musical "enlightenment" of the eponymous Anton Ivanovich Voronov, an old, stodgy organ professor who is interested only in the "serious" music of J.S. Bach. His daughter, Sima, however, wishes to become an operetta singer and falls in love with a composer of "light" music, Aleksey Mukhin, which upsets the professor greatly. Thanks to a miraculous intervention by Bach himself, Anton Ivanovich ultimately sees his error and accepts Muhkin, going so far as to perform the organ part in Mukhin's new symphonic poem. While largely a lighthearted and fun tale, the caricature and censure of another young, but veiled "formalist" composer, Kerosinov, reflects the darker side of contemporary Soviet musical aesthetics. In the way that it does and does not work out the uneasy relationship between serious, light, and formalist music, I argue that Anton Ivanovich serditsya realistically reflects the paradoxical nature of Soviet musical politics in the late 1930s.
\end{abstract}

Alexander Ivanovsky's 1941 film Anton Ivanovich serditsya (Anton Ivanovich is Upset, hereafter AIS) tells the story of Anton Ivanovich Voronov (from voron, "raven"), a venerated professor at the conservatory who idolizes the music of "serious" composers, particularly J.S. Bach. ${ }^{1}$ His earnestness is established from the very start: we first see him in deep contemplation and reverence performing Bach's somber Passacaglia and Fugue in C minor, BWV 582, which accompanies the film's opening credits. Anton Ivanovich becomes upset, however, when he learns that his angelic daughter Sima (short for Seraphima, "seraphim"), who is training to become a singer, prefers "lighter" musical fare. His anger boils over when she falls in love with the young composer Alexey Mukhin (from mukha, "fly"), who is just completing a new operetta in which Sima will take the lead role. The expected, and necessary, reconciliation occurs just before the end of the film when Anton Ivanovich is visited in a dream by Bach himself, who convinces the professor that all music can be good, so long as it is well crafted. The professor thus comes to terms with his daughter's love for light music (and for Mukhin) and agrees to perform the organ part in Mukhin's new symphonic poem, a rousing performance of which ends the film. The film is thus, ostensibly, a story "about the justification for the existence of the light genre in music."2

But there are two other composers involved in the film who must also be taken into consideration. The first is an avant-gardist named Kerosinov (from kerosin, "kerosene"), who has been working on a "Physiological Symphony" for nine years and whose elitist attitude toward music is generally ridiculed

\footnotetext{
${ }^{1}$ The film can be found online at https://youtu.be/sWQqNK 2BsM (accessed June 1, 2018).

${ }^{2}$ Aleksandr Venyaminovich Macheret and Nina Alekseyevna Glagoleva, Sovetskiye khudozhestvennïye fil'mï: annotirovannïy katalog [Soviet Feature Films: An Annotated Catalog], vol. 2 (Moscow: Iskusstvo, 1961), 252. Unless otherwise noted, all translations are my own.
} 
throughout the film (we never actually hear any of his music). The other is Dmitry Kabalevsky, the real Soviet composer behind Mukhin's music. To distinguish between these two may seem pedantic, but it is important when considering how the film embodies the musical and film aesthetics of its time and place, that is, how it fulfills the mandates of Socialist Realism. Despite the very unrealistic dream sequence mentioned above, the creative team went to lengths to make other elements of the film quite realistic-it is, for example, set contemporaneously, characters refer to current musical debates, and it features no nondiegetic music. The latter is particularly important when considering the film's generic identity: it seems to continue the trend of musical comedies produced in the Soviet Union in the 1930s, but in the way that all music is presented diegetically it instead reflects the increased political pressure at the end of the decade for comedies-musical and non-to become more realistic.

As such, I argue that AIS manifests contemporary debates about the role of realism in comedy film and the place of light music within Soviet musical aesthetics. It does so in part by eschewing the typical audio-visual mechanisms of the film musical (and, indeed, of narrative film too), leading to a heightened sense of realism. The film plays this out in an engaging and humorous manner that pits father against daughter, includes a love story, and, of course, ends in a reconciliation of serious and light musical styles. But as we will also see, behind this charming façade there lies a more sinister truth about the types of music that were valued at the time. In what follows, I first contextualize AIS within the tradition and style of Soviet musical comedy films of the 1930s before turning to how it represents and assigns value to different musical genres. I conclude by briefly considering the film's unfortunate legacy.

\section{Laughter and/or Realism?}

As mentioned, AIS falls into a long line of musical comedy films produced in the Soviet Union in the 1930s and early 1940s. These films—the best-known of which include Volga-Volga (1938, dir. Grigory Alexandrov) and The Rich Bride (Bogataya nevesta, 1938, dir. Ivan Pïr'yev)-became emblematic of this period not only because of their wild popularity at the time, but also because they were later cited as symbols of the "varnished" fantasy worlds promulgated during High Stalinism (including by Nikita Khrushchev in his infamous "secret speech" to the Twentieth Party Congress in 1956). ${ }^{3}$ Since the fall of the Soviet Union, scholars have begun to reassess this repertory in an effort to come to terms with how it represented, among other things, a reconciliation of the entertainment needs of the masses with the ideological and aesthetic interests of the nascent Soviet state. ${ }^{4}$

While music is obviously central to the style of these film musicals, AIS can be grouped in with a specific subset of these films, namely those whose narratives are specifically about music and its place in

\footnotetext{
${ }^{3}$ Richard Taylor, "Red Stars, Positive Heroes, and Personality Cults," in Stalinism and Soviet Cinema, ed. Derek Spring and Richard Taylor (New York: Routledge, 1993), 70.

${ }^{4}$ See Richard Taylor, "Ideology as Mass Entertainment: Boris Shumyatsky and Soviet Cinema of the 1930s," in Inside the Film Factory: New Approaches to Russian and Soviet Cinema, ed. Richard Taylor and Ian Christie (New York: Routledge, 1991), 193216; Trudy Anderson, "Why Stalinist Musicals?," Discourse 17, no. 3 (1995): 38-48; Richard Taylor, "The Illusion of Happiness and the Happiness of Illusion: Grigorii Aleksandrov's The Circus," The Slavonic and East European Review 74, no. 4 (1996): 601-20; Richard Taylor, "Singing on the Steppes for Stalin: Ivan Pyr'ev and the Kolkhoz Musical in Soviet Cinema," Slavic Review 58, no. 1 (1999): 143-59, https://doi.org/10.2307/2672993; Richard Taylor, "But Eastward, Look, the Land Is Brighter: Towards a Topography of Utopia in the Stalinist Musical," in 100 Years of European Cinema: Entertainment Or Ideology?, ed. Diana Holmes and Alison Smith (Manchester: Manchester University Press, 2000), 11-26; Evgeny Dobrenko, "The Singing Masses and the Laughing State in the Musical Comedy of the Stalinist 1930s: The Problem of 'Popular Spirit' in Socialist Realist Aesthetics," in Reflective Laughter: Aspects of Humour in Russian Culture, ed. Lesley Milne (London: Anthem Press, 2004), 131-45; Rimgaila Salys, The Musical Comedy Films of Grigorii Aleksandrov: Laughing Matters (Chicago: Intellect Ltd, 2009).
} 
Soviet culture. In these films, then, music is not just a stylistic or generic device, but forms the subject matter of the film as well. The most famous predecessors in this regard are Alexandrov's Jolly Fellows (Vesyolïye rebyata, 1934) and Volga-Volga, as well as Ivanovsky's own A Musical Story (Muzïkal'naya istoriya), released in 1940, just a year before AIS. ${ }^{5}$ In the former two, Alexandrov addresses the question of how different musical styles can coexist within Soviet musical culture. In both films, reconciliation of these styles is achieved at the end when blends of high and low musics are centralized and legitimized by official institutions. In Jolly Fellows, for example, it is a provincial shepherd and folk musician who finds his greatest success at the Bolshoy Theater, leading his band of "Jolly Fellows" in classical, jazz, folk, military, and other renditions of the film's theme song: Isaak Dunayevsky's hit tune "March of the Jolly Fellows." In Volga-Volga, the melding of classical and folk traditions by two initially opposed ensembles from a small, remote village on the Volga River enables victory at the climactic national musical Olympiad in Moscow. The ultimate message of both films, then, is that "authentic" Soviet musical culture originates from the common man, and communicates with the mass viewer best through an equalization and validation of many diverse styles and genres, both high and low. Ivanovsky's A Musical Story is similar: though it takes place fully in Moscow (i.e., the center), it is also a tale of high and low fusing in order to inspire the mass viewer. It tells the story of an everyman (a taxi driver) whose discovery of a musical talent (he can sing opera) empowers him to communicate deeply and emotionally with the mass spectator (through an amateur production of Chaikovsky's Eugene Onegin at the local Club of Auto Transport Workers). As Anna Nisnevich has written, Ivanovsky uses the tradition of Romantic opera to "stage and perpetuate [the] assimilation" of the Russian classics as a way "not only [to gain] historical perspective ... but also [to develop] special receptivity to the varied and complex forms of the human imaginary (i.e., honing one's aesthetic insight)." An important element that unites all of these films is thus a desire to reconcile the popular with the serious as a means of advancing the cultural and ideological enlightenment of the viewer.

But AIS is unique even among these films. Unlike the others, its music is entirely diegetic: there is not a single moment in the film in which the source of the onscreen music, particularly the accompaniment to any singing, is not explicitly clear. All the music making in the film is, in other words, completely "realistic." This is curious, for if we accept Rick Altman's claim that a defining feature of the film musical is that non-diegetic music at times "takes over" the diegesis during the musical numbersthat is, all diegetic actions are guided by and synchronized to non-diegetic music - then AIS does not, in this sense, qualify as a musical. ${ }^{7}$ Such moments of audiovisual reversal are crucial to the aesthetic of the film musical, Altman argues, because they open up utopian spaces in which the film's ideological work can be done. In the numbers, where characters can suddenly, and unrealistically, hear the non-diegetic accompaniment, the border between the real and ideal is blurred such that we experience the characters' true (i.e., most realistic) thoughts, feelings, and dreams. In Soviet film musicals it meant that music could create idealized spaces in which the goals of the Socialist Realist future could be depicted in the here and now. This description accurately encompasses the style of Alexandrov's and Pïr'yev's earlier musicals.

\footnotetext{
${ }^{5}$ On the music in these films, see Peter Kupfer, “'Our Soviet Americanism’: Folly Fellows, Music, and Early Soviet Cultural Ideology," Twentieth-Century Music 13, no. 2 (September 2016): 201-32, https://doi.org/10.1017/S1478572216000049; Peter Kupfer, "Volga-Volga: 'The Story of a Song,' Vernacular Modernism, and the Realization of Soviet Music," The Fournal of Musicology 30, no. 4 (2013): 530-76, https://doi.org/10.1525/im.2013.30.4.530; Anna Nisnevich, "Listening to Muzykal'naia istoriia (1940)," in Sound, Speech, Music in Soviet and Post-Soviet Cinema, ed. Lilya Kaganovsky and Masha Salazkina (Bloomington: Indiana University Press, 2014), 193-211.

${ }^{6}$ Nisnevich, "Listening to Muzykal'naia istoriia (1940)," 203.

${ }^{7}$ See chapter 4 of Rick Altman, The American Film Musical (Bloomington: Indiana University Press, 1987), esp. 62-74.
} 
And even though A Musical Story ostensibly marked a shift in the level of musicality of Soviet musical films, it too is marked by moments in which the main character Petya sings Chaikovsky "to himself" in ordinary situations (e.g., driving his taxi or shaving) to the sounds of a full off-screen orchestral accompaniment. ${ }^{8}$ AIS is thus not a muzikal'naya komediya (musical comedy) in the same stylistic sense as Alexandrov's, Pïr'yev's, and Ivanovsky's earlier films.

Several Soviet critics recognized this too. An early reviewer underscored how music formed the subject of the film: "the musical content is organically connected to the subject and is the basis of the dramatic action. The basic theme of the script is the theme of the breadth of Soviet musical culture, in which both serious, 'great' and so-called 'light' music find their place, but the real matter [is] elevated [visokiy] taste in music. The basic conflict of the script ... provides the opportunity to imbue all the twists and turns of the plot with music and moreover to do so very intelligibly." Discussing the film 20 years later in a book on Kabalevsky's film music, Dina Daragan also noticed that while the film is "in many ways ... close to [the musical comedy], ... we do not encounter extended symphonic episodes, music 'behind the picture,' such as the usual 'musical subtext' of the films" of other Soviet directors. ${ }^{10}$ As we will see below, even the one overtly unrealistic moment in AIS that should, according to the generic codes of the film musical, be accompanied by music - a dream sequence-is not. It is thus perhaps most accurate to describe the film not as a musical comedy in the stricter stylistic sense of the term, but rather as a comedy about music.

I have belabored this distinction because it focuses attention on the "realism" of the film and the values it promulgates. Indeed, as Anna Toropova has shown, the shift toward realism in Soviet comedies of the later 1930s was not a coincidence. The authorities had been pressuring the industry for years to make more realistic comedies, resulting in a stylistic shift that had, by the end of the decade, "been firmly established." ${ }^{11}$ Nevertheless, certain cultural watchdogs were still not pleased. In a speech at a meeting of Soviet filmmakers in May 1941, Chairman of the Supreme Soviet Andrey Zhdanov, for example, noted that there was still a general need to improve the ideological content and artistic quality of Soviet cinema, but that the problem was particularly acute in comedy films: "if in the sphere of artistic films we have quite a few failures, then with respect to comedies this situation is getting even worse. For a long time we have not had Soviet comedies, with the exception of a few films. Here it emerges that having achieved a certain level in the creation of our Soviet film comedies, the latest films, they seem to try to reach this level and then return to the initial step." ${ }^{12}$ As an example, he chastised the film Hearts of Four (Serdtsa chetiryokh, dir. Konstantin Yudin, 1941) for relying on a thin plot, on the "simplistic devices" of slapstick to elicit thoughtless laughter, and on characterizations that do not properly reflect Soviet reality: "Does this really correspond to Soviet life? What does this attest to? It attests to a certain dangerous detachment from reality." 13

At the same time, the fate of AIS hung in the balance due to its own supposed lack of realism. Just a few weeks earlier, at the end of March, the director of the Agitprop Department, Georgy Alexandrov,

\footnotetext{
${ }^{8}$ It could be argued that the accompaniment comes from the radio, but we hear no other singing voice save for Petya's.

9 “Anton Ivanïch Serditsya [Anton Ivanovich Is Upset]," Kadr, October 26, 1940.

${ }^{10}$ Dina Daragan, Kinomuzïka D. Kabalevskogo [The Film Music of D. Kabalevskiy] (Moscow: Muzika, 1965), 38-39.

${ }^{11}$ See Anna Toropova, “'If We Cannot Laugh like That, Then How Can We Laugh?': The 'Problem' of Stalinist Film Comedy," Studies in Russian and Soviet Cinema 5, no. 3 (2011): 335-51, here 339, https://doi.org/10.1386/srsc.5.3.335_1.

12 “'Uncorrected Transcript of Introductory Remarks by TsK VKP(b) Secretary A. A. Zhdanov at a Meeting of Cinematographers at the TsK VKP(b),' 14 May 1941, RGASPI. f. 77, Op. 1, Ll. 1a-7," in Soviet Culture and Power: A History in Documents, 1917-1953, ed. Katerina Clark and Evgeny Dobrenko (New Haven: Yale University Press, 2007 ), 274.

${ }^{13}$ Zhdanov, 275.
} 
seemed to indicate in a report to the Central Committee on the production plan for cinema in the coming year that AIS had the potential to reflect reality by placing it in the category of "films of everyday character." ${ }^{14}$ But he went on to point out how the film actually did not reflect Soviet life:

In the script of the musical film Anton Ivanovich serditsya the authors (Ye. Petrov and Munblit) proceeded as if the most important thing in a musical film is jolly [vesyolaya] music, and so there should not be any ideas in it. The people in the script are purposefully made to look stupid (the director of the theater, for example, crawls on all fours into the orchestra with a note in his teeth). The complete lack of ideology and the absence of the Soviet spirit in the script allow the actions in it to be transferred into any capitalistic country. ${ }^{15}$

As a result, the Agitprop Department recommended excluding AIS from the production plan (along with several others) due to its "complete unfitness." 16 Though the scene with the director crawling through the orchestra pit was left in the film, the script was revised in other ways; a scene (about which more below) was added, for example, in which reference is made to "official" contemporary practices concerning folk music, thus bringing the film closer to Soviet reality. ${ }^{17}$ But what the comments by Zhdanov, Alexandrov, and others indicate is that the authorities wanted comedy films to "put laughter in the service of consolidating Stalinist values" by using it sparingly and strategically to reinforce the positive and life-affirming values of Socialist Realism. ${ }^{18}$ In this way, the "realistic comedy" shared fewer features with the musical comedies mentioned above and was instead closer to contemporary Socialist Realist dramas in which, most often, the "socialist hero has to overcome difficulties, such as bureaucracy, arrogance or stupidity, or natural obstacles, such as storms or cold."19

From this point of view, the hero of AIS is not the eponymous Anton Ivanovich, but rather Mukhin, who fights to legitimize himself and his open-minded views on musical taste in the face of opposition from the stodgy professor and Kerosinov. Let us turn to the film itself to see how these debates unfold. Ultimately, we will see that by silencing Anton Ivanovich and Kerosinov's deviant voices, Mukhin's triumphant hybrid musical taste is presented as the path forward for Soviet music.

\footnotetext{
14 "Dokladnaya zapiska nachal'nika upravleniya propagandï i agitatsii TsK VKP(b) G. F. Aleksandrova sekretaryam TsK VKP(b) A. A. Andreyevu, A. A. Zhdanovu, G. M. Malenkovu 'O plane proizvodstva khudozhestvennïkh fil'mov na 1941 god' (31 Marta 1941 g.) [Memorandum of the Head of the Department of Propaganda and Agitation of the Central Committee of the All-Union Communist Party (Bolsheviks) G. F. Aleksandrov to the Secretaries of the Central Committee of the All-Union Communist Party (Bolsheviks) A. A. Andreyev, A. A. Zhdanov, G. M. Malenkov 'About the Production Plan for Feature Films in the year 1941' (31 March 1941)]," in Kino na voyne: Dokumentï i svidetel'stva [Cinema During the War: Documents and Records], ed. V. I. Fomin (Moscow: Materik, 2005), 26.

${ }^{15}$ Aleksandrov, 26. The director crawls through the orchestra pit with a note in his mouth instructing the conductor to ignore a falsely ordered transposition of an aria up by three steps. The moment in question can be seen at https://youtu.be/sWQqNK_2BsM?t=3725 (accessed June 1, 2018). See also n. 21 below.

${ }^{16}$ Aleksandrov, 27.

${ }^{17}$ The changes can be seen by comparing the officially published script of the film with the final version. See "[Anton Ivanovich serditsya] [Anton Ivanovich Is Upset]," in Izbrannïye stsenarii sovetskogo kino [Selected Scripts from Soviet Cinema], vol. 3 (Moscow: Goskinoizdat, 1949), 473-517. Whatever alterations were made more than sufficed, however, as not only was the final version of $A I S$ chosen by the Agitprop Department to be sent abroad in 1942 as an example of Soviet filmmaking, but it fell into the top group (of only nine films, including Alexander Nevsky) in terms of the number of exemplars sent out. See "Sprakva nachal'nika upravleniya propagandi i agitatsii TsK VKP(b) G. F. Aleksandrova sekretaryu TsK VKP(b) A.S. Shcherbakovu 'Ob otpravke za granitsu sovetskikh kinofil'mov' (Ne pozdneye 18 Marta $1942 \mathrm{~g}$.) [Notification of the Head of the Department of Propaganda and Agitation of the Central Committee of the All-Union Communist Party (Bolsheviks) G. F. Aleksandrov to the Secretary of the Central Committee of the All-Union Communist Party (Bolsheviks) A.S. Shcherbakov 'About the Foreign Distribution of Soviet Films' (Not later than 18 March 1942)]," in Kino na voyne: Dokumentï i svidetel'stva [Cinema During the War: Documents and Records], ed. V. I. Fomin (Moscow: Materik, 2005), 559.

${ }_{18}$ Toropova, "If We Cannot Laugh like That," 340.

${ }^{19}$ Peter Kenez, Cinema and Soviet Society from the Revolution to the Death of Stalin, new ed. (London: I.B. Tauris, 2001$), 149$.
} 


\section{Serious vs. Light}

The central conflict of the film, between serious and light music, is established early on in a conversation between Anton Ivanovich and Sima's voice teacher, Andrey Apollonovich. Having overheard her rehearsing the aria "Je veux vivre" from Charles Gounod's Romeo and Juliet, Anton Ivanovich becomes upset and engages Andrey Apollonovich in a discussion about the merits (or lack thereof) of light music (Example 1).

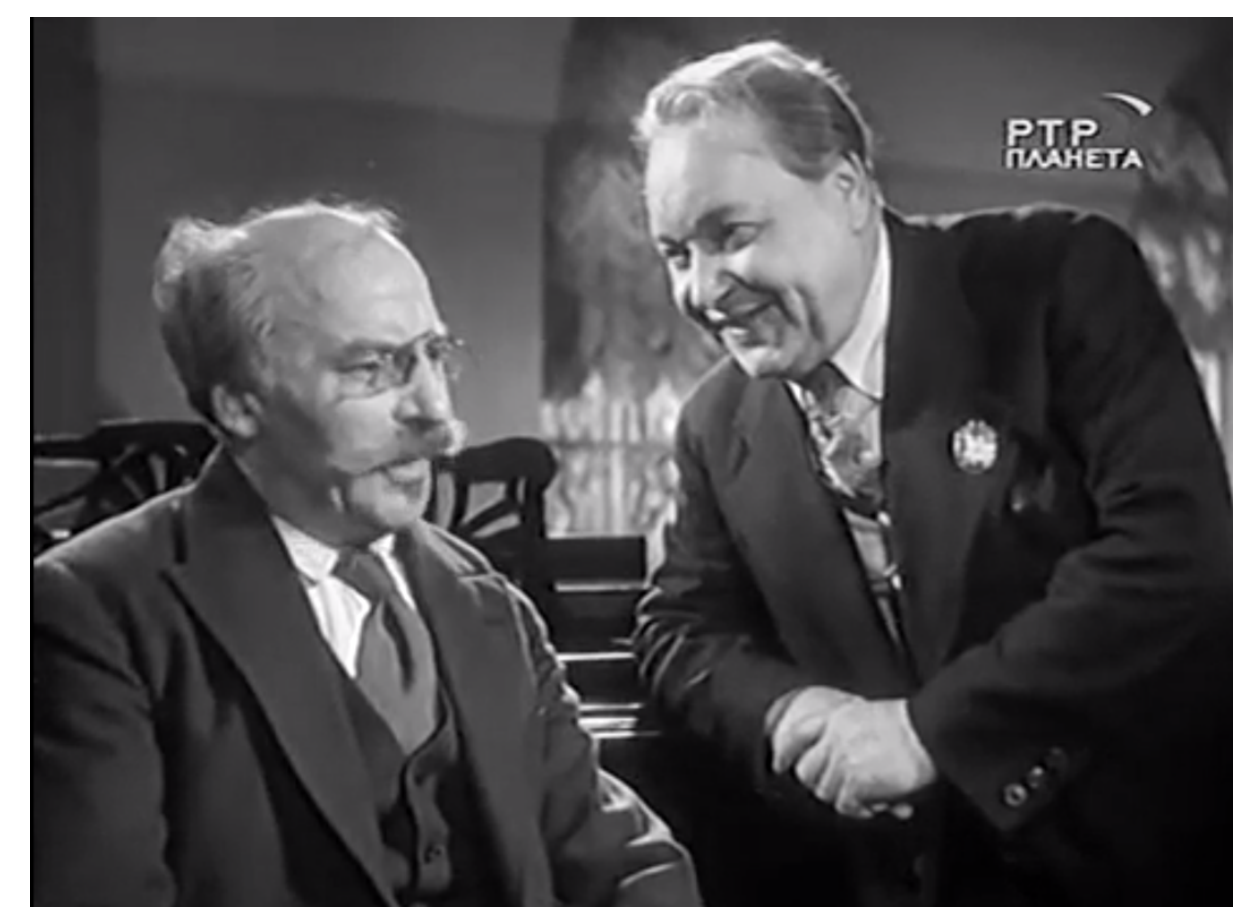

Example 1: The Musical Debate

See video: http://dx.doi.org/10.3998/mp.9460447.0012.201

Anton Ivanovich: Simochka, go home without me, I'd like to speak with Andrey Apollonovich.

Sima: Okay, goodbye Andrey Apollonovich.

Andrey Apollonovich: Goodbye Sima. Please sit, Anton Ivanovich. [Gestures for him to sit.

AI sits on the piano bench.] Your daughter is a future prima donna, a star!

AI: Andrey Apollonovich, you are making my daughter into a singer. I believe, a good singer.

Maybe even a very good singer. But what I saw and heard today-you will allow me to speak openly?

AA: Please, go ahead!

AI: What I saw and heard today upset me deeply. Andrey Apollonovich, we, each in our own areas, have one important duty—we prepare students for the great mission to bring music to the masses! We must foster in our students strict taste.

AA: Very, very true.

AI: Then how could you give my daughter this—I don't even know what to call it—some kind of cabaret song [shansonetka] to sing on her graduation exam?!

AA: Please, please Professor ... 
AI: No, you please! When I listen to serious music, it makes me want to stand [he stands] and remove my hat. But this, this is something to listen to while lounging on the sofa, it's not music, it's ... some kind of dance!

AA: Oh, you know Professor ...

AI: Please! Johann Sebastian Bach ...

AA: Johann Sebastian Bach was a jolly fat man!

AI: Johann Sebastian Bach composed chorales. And do you know what that is, a chorale? It's a prayer.

AA: Johann Sebastian Bach composed dance suites. [AA sits at piano and plays opening measures of Gavotte I from the English Suite No. 3 in G minor, BWV 808.] Ha, what do you think?

AI: That ... is the joke of a genius! This is Bach. [AI sits and plays a chorale-like passage. ${ }^{20}$ ] And Beethoven, this genius, mad, unforgotten man? What's he? Was he also a jolly fat man? What about this? [He plays the opening measures of the "Pathétique" Sonata, Op. 13.]

AA: [Pushing AI from the piano bench] Beethoven also wrote fun drinking songs. [He plays and sings opening of the "Trinklied" from the Scottish Songs, Op. 108.] Ah, what's that to you? Also the joke of genius?

AI: Beethoven wrote that as a commission.

AA: As a commission!?

AI: Yes!

AA: And Verdi, he composed Aida also as a commission?! Imagine, for the opening of the Suez Canal.

AI: Verdi!? This ... organ grinder [sharmanshchik]!

AA: How dare you, Professor! [Banging keyboard as he speaks.]

AI: I dare! [Banging keyboard as he responds.]

AA: You ... are a dangerous sectarian! [Begins to walk away.]

AI: Stop! And you ... you are n-n-not a serious musician. [Stuttering as he tries to find the right insult.]

AA: If you were not the father of my favorite student ... [He says from across the room, but is interrupted.]

AI: And if you were not the teacher of my favorite daughter ... [They approach each other.]

AA: Fine, let's leave it at that.

AI: Let's leave it.

AA: Let's leave it.

AI: Let's leave it.

AA: What exactly do you want from me, Professor?

AI: What I want to tell you, Professor, is that I want to make my daughter into a chamber singer.

AA: My god!

AI: Yes, yes, a chamber singer, with a very strict and serious repertoire. Bach, Handel, Gluck, Haydn.

\footnotetext{
${ }^{20}$ Despite best efforts—including consultation with several leading Bach experts, practicing church musicians, and organists; messages to the listhost of the American Musicological Society; and extensive perusal of the Bach catalog-I have not able to identify this as an actual passage of Bach (I thank Michael Conrady in particular for his help in analyzing this excerpt). This is odd given that all other musical excerpts chosen for this musical debate are readily identifiable, and because Bach plays such a central symbolic role in the film. Indeed, this very passage of music returns later in the film when Mukhin attempts to dupe Kerosinov (see Example 7 below). My best guess is that this is a sort of meta-joke on the part of Kabalevsky: like Andrey Apollonovich and later Kerosinov, the viewer is none-the-wiser that Kabalevsky can convincingly imitate the style of Bach, just as he convincingly "imitates" other musical styles throughout the film. I have, however, found no definitive evidence to support such a conclusion.
} 
AA: Do you understand, bigot [izuver], that you will ruin your daughter? Simochka has a light, graceful, jolly talent. But you want to make a roach out of her. But Simochka's calling is the light genre. Do you hear me? The light genre!

AI: Do not tell me about this word "light" genre! It doesn't exist in nature. Only vulgar, bad music exists in nature. It's all stupidity. [He begins to walk away.]

AA: Professor Voronov, I feel sorry for you!

The terms of the aesthetic debate are set rather starkly here: Anton Ivanovich believes the faculty of the conservatory has a social calling to train their students to bring only the most serious music to audiences, music of the strictest taste, music not tied to worldly events (like commissions), music that demands respect and spiritual contemplation. The light genre, he believes, is unnatural and deserves only to be scoffed at. Andrey Apollonovich, on the other hand, understands that even the greatest, most serious composers wrote lighter works, some of which happened to be tied to the political or historical contexts of the times. But, most importantly, they found balance between fun and serious music.

With this exchange, Anton Ivanovich's position on light music is clearly established. And it is a steadfast one. Even when Sima falls in love with Mukhin, Anton Ivanovich's own musical tastes come first. When she brings Mukhin home to meet her parents, Anton Ivanovich is shocked to hear Mukhin perform a foxtrot from his new operetta. Unable to even call Mukhin by his name, Anton Ivanovich kicks "this person" out of the house. And later, to add insult to injury, when Sima finally headlines in Mukhin's new operetta, Anton Ivanovich cannot even manage to stay for the entire performance. The light genrewhether "vulgar" classical works or entire genres like operetta—clearly has no place in Anton Ivanovich's conception of music.

But Mukhin, like Andrey Apollonovich, sees no problem with being a composer of both serious and light music or with taking light music seriously. His view on musical taste is also established early in the film, in a scene immediately following the exchange between Anton Ivanovich and Andrey Apollonovich discussed above. The scene begins with the presentation of his latest operetta to the theater company at the conservatory. Initially, he receives a very warm reception: they are thrilled to begin working on it, but the star soprano, an older singer named Kholodetskaya (from kholod, "cold"), cannot hit the required high notes. Both the conductor and director of the company suggest transposing the number down to accommodate her, but Mukhin is vehemently opposed to this idea, and becomes outraged when Kholodetskaya's husband Kibrik (a member of the company himself) tries to convince him to do so (Examples 2a-c). 


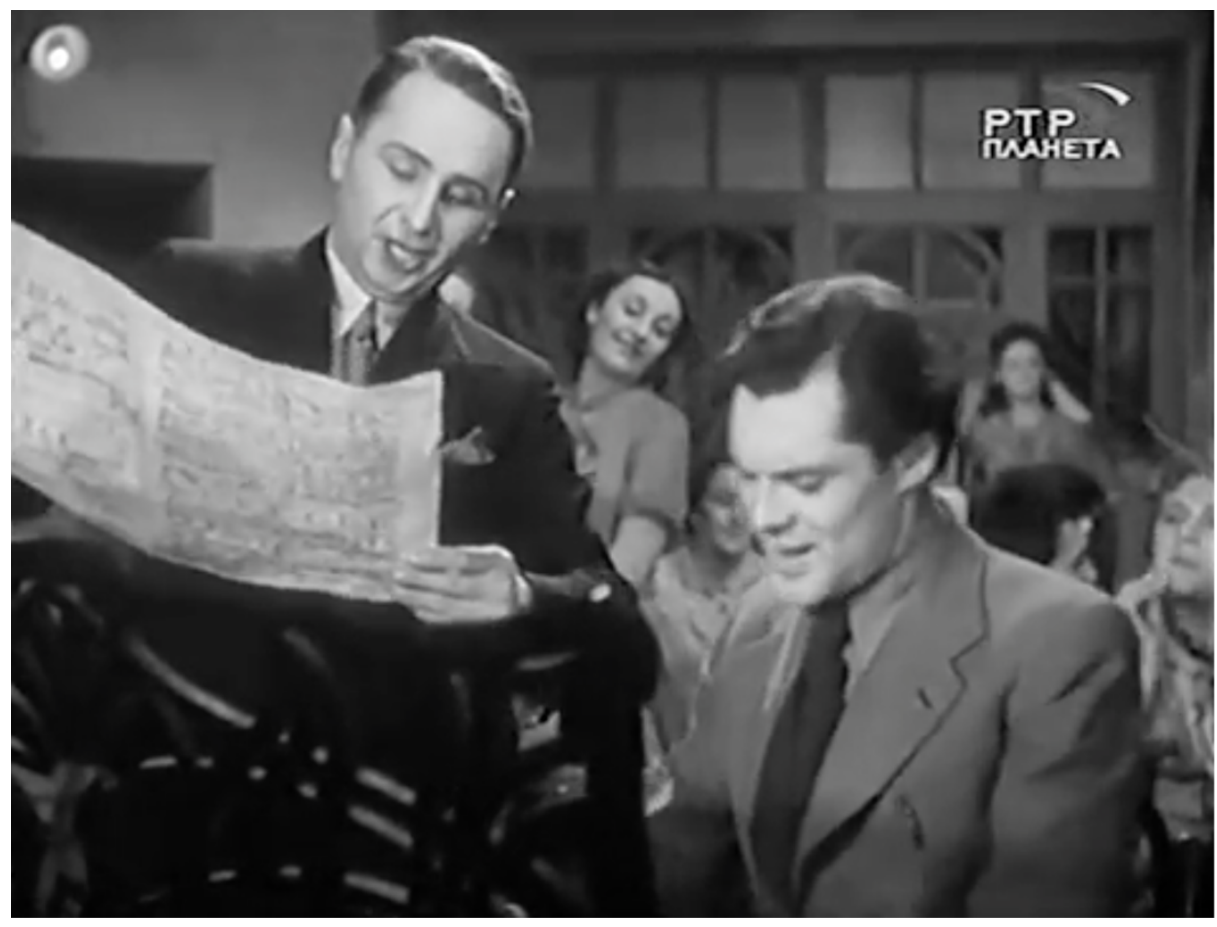

Example 2a: Mukhin previews his operetta for the assembled company

See video: http://dx.doi.org/10.3998/mp.9460447.0012.201

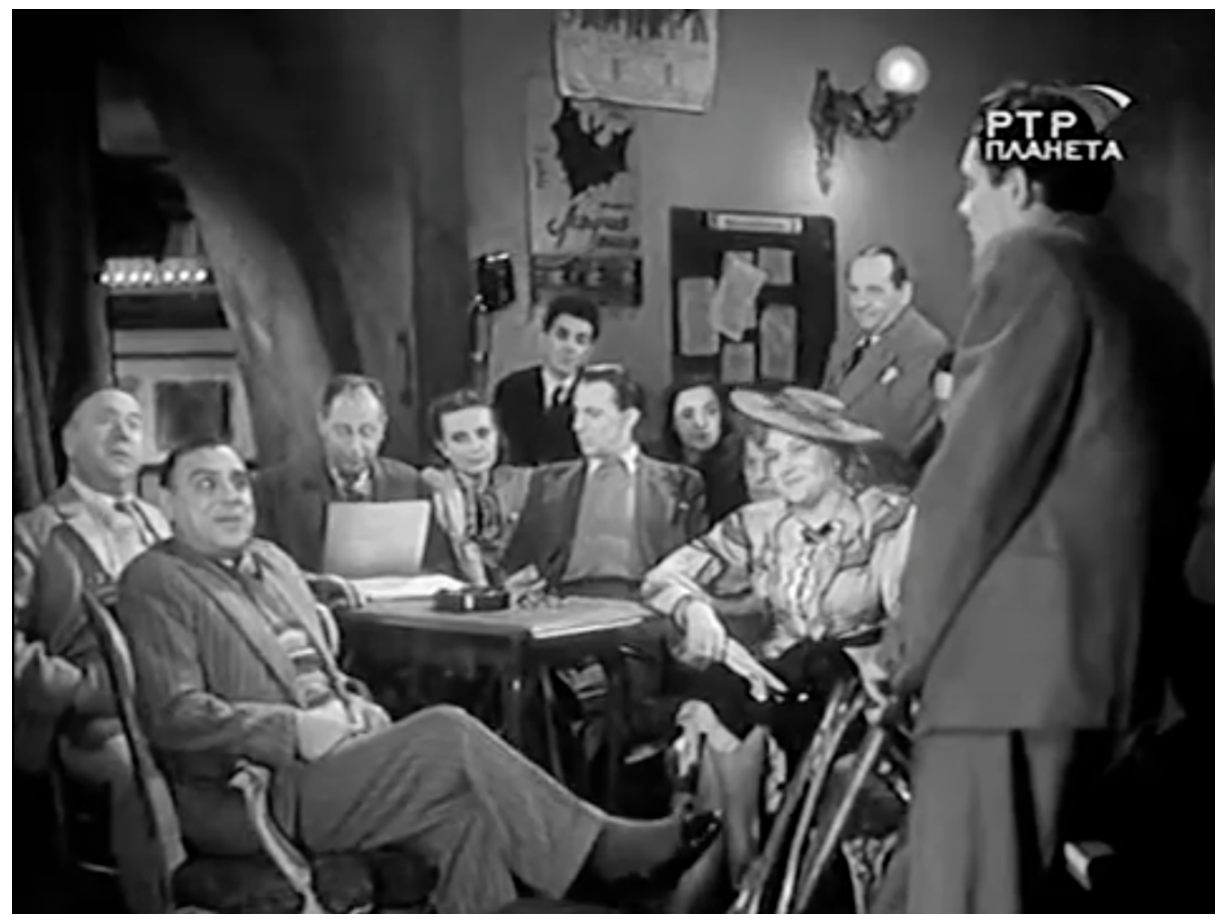

Example 2b: Discussion about the operetta after the preview See video: http://dx.doi.org/10.3998/mp.9460447.0012.201 
Kibrik: Excellent music. You write simply brilliant stuff. But it can't be sung in the way you have written it.

Skvoreshnikov [the company director]: I don't understand.

$\mathrm{K}$ : It's simple. It's very simple. You have written the part of the heroine such that not a single singer from our theater can sing it. Not even an outstanding-and you'll excuse me if I speak this way about my wife-not even an outstanding singer like Yadya [Kholodetskaya].

Others: Yes, yes. Completely true.

Kholodetskaya: It simply isn't possible. This hellish [adskaya] tessitura... Four times the high $\mathrm{Bb}$. Maybe the comrade composer assumed that this aria would be sung by [Amelita] Galli-Curci [Italian coloratura soprano (1882-1963)] or Toti Dal Monte [stage name of Italian soprano Antonietta Meneghel (1893-1975)]! Four times the high Bb!

$\mathrm{K}$ : But Yadya's highest note is F.

Kh: Please, my highest note is G! It seems to me, though, that we don't need to speak about that. So, it's all clear.

S: Please, please, nothing is clear. We can make it lower. By how much do we need to lower it?

Conductor: By four steps. We can transpose it.

S: Oh, perfect. Alexey Petrovich [Mukhin] can do this in a minute.

Mukhin: No, I don't agree with this. I will not transpose this part.

$\mathrm{K}$ : Alyosha, have you gone crazy?

S: Everybody does it.

M: And it's very sad that they do so. I am not going to do it. I don't want to.

$\mathrm{K}$ : Come to your senses, Alyosha! It's the light genre after all. [Performs a slapstick clap and jump dance maneuver]. Operetta.

M: But I don't write for this Yakov Grigoryevich [Kibrik]. [Mukhin mocks the dance maneuver.] I have no patience for this expression "light genre." In my opinion, that's a haven for hacks. It is my point of view that one needs to write seriously and decisively regardless of the genre, because music is music.

K: And who says that? Beethoven? Rimsky-Korsakov? Strauss? [The others laugh.]

M: If you really want [an answer]? Their student says this. I don't want my teachers to blush on my account. Understood?

$\mathrm{K}$ : Don't you understand that Yadya can't sing your operetta?

M: Well, then what is to be done? Somebody else will sing it.

Kholodetskaya storms out of the room, dragging Kibrik with her. 


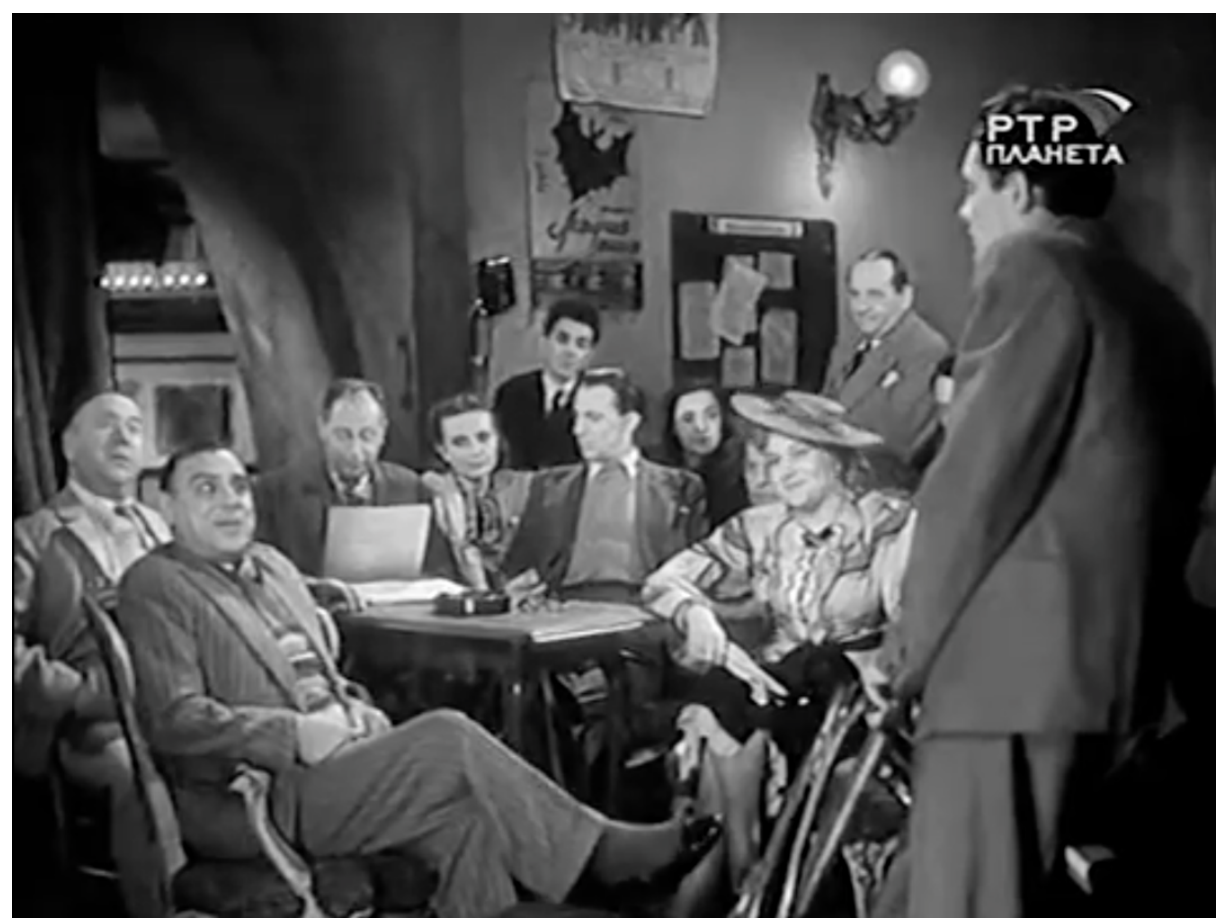

Example 2c: Conclusion of scene

See video: $\underline{\text { http://dx.doi.org/10.3998/mp.9460447.0012.201 }}$

S: Aleksey Petrovich, is there nothing you can think up? We have to bow to the feet of our Yadviga Valentinovna [Kholodetskaya].

M: Keep in mind Stepan Stepanovich [Skvoreshnikov] that I won't change a single note of my operetta.

S: My darling, we all very much like your operetta.

M: If you like it, find a different singer. Try to find one among the younger singers.

Kibrik's characterization of the operetta as some kind of slapstick circus comedy incenses Mukhin, who feels that transposing the part will harm the work's musical integrity. Sounding oddly like Anton Ivanovich, he professes having no respect for light music, at least not when executed poorly or without purpose. So long as the composer is thoughtful and honest, and demonstrates craft, "music is music." By implication, any musical style or genre can be worthy. Indeed, Mukhin considers himself a student of Beethoven, Rimsky-Korsakov, and Strauss, all of whom influenced him regardless of the genre in which they, or he, compose. To compromise his music by transposing it down would not only do himself a disservice, but them as well. Mukhin clearly respects the traditions and values of serious music, but believes they can be applied just as equally to light music. Thus, in contrast to Anton Ivanovich, Mukhin's view is far more democratic, but he is no less adamant than the professor about defending it. Light music should be taken seriously. ${ }^{21}$

\footnotetext{
${ }^{21}$ However, it must be noted that Mukhin does later agree to a transposition of part of the operetta's central aria when, as the result of a devious plan concocted by Kholodetskaya in order to exact revenge, he believes that Sima herself has requested, after the premiere of the operetta has begun, a last-minute transposition of the ending of the aria up by three steps. It seems that only love will sway Mukhin. But his horror upon discovering that Sima has no idea about this ruse and his subsequent
} 
These two strands-Anton Ivanovich's hyperserious exclusivity and Mukhin's broad inclusivity—are juxtaposed in humorous ways several more times throughout the film, but are, as expected, eventually reconciled. This is only achieved, though, through a miraculous intervention. Having returned home after his early departure from the performance of the operetta, Anton Ivanovich sits down dejectedly in his armchair, gazes despondently at the portrait of his beloved Bach, and closes his eyes (Example 3).

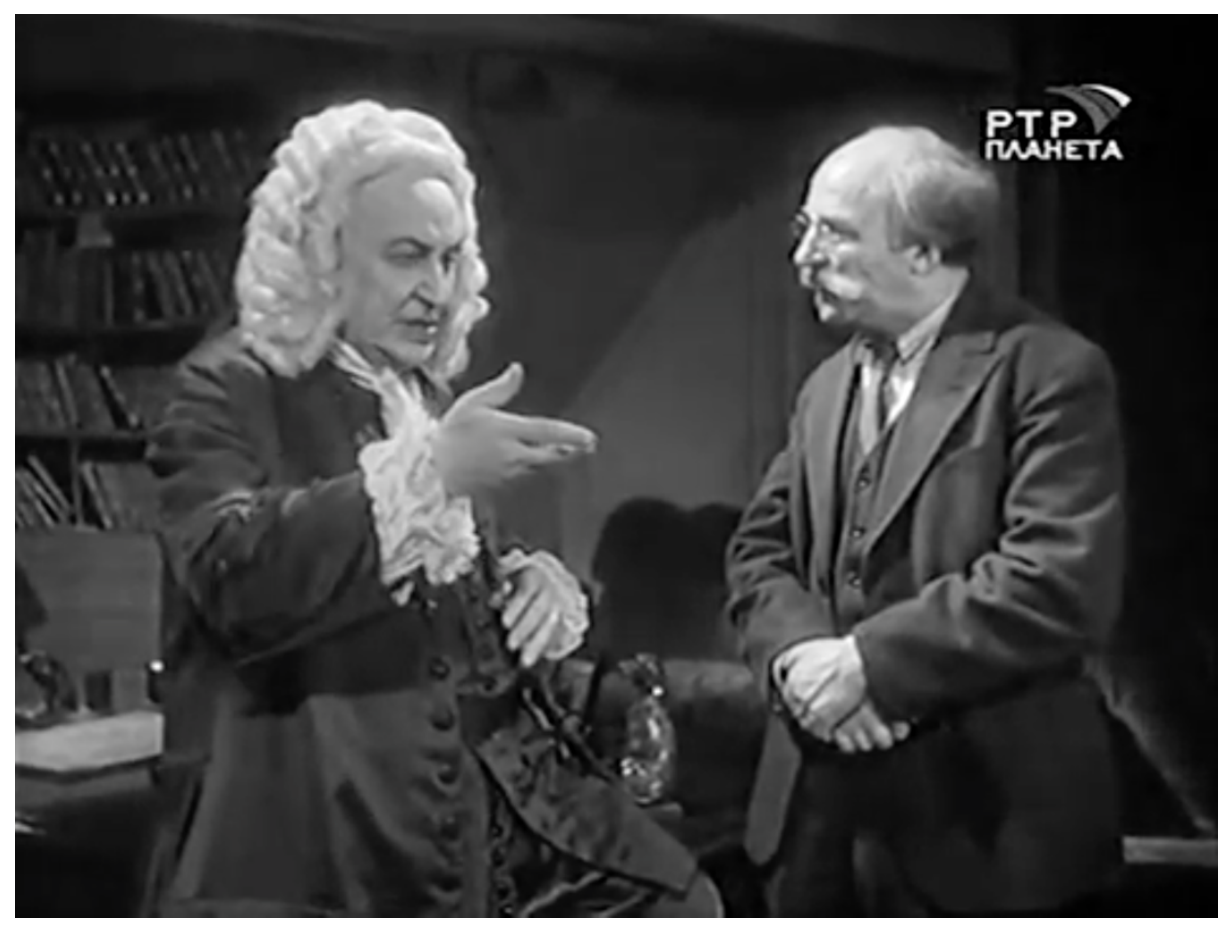

Example 3: Anton Ivanovich's Dream

See video: http://dx.doi.org/10.3998/mp.9460447.0012.201

[Anton Ivanovich falls asleep, Bach steps out of the painting hanging on the wall.]

Anton Ivanovich: Johann Sebastian Bach?!

Johann Sebastian Bach: At your service, Maestro.

AI: How did you get here?

[JSB points at the painting, they laugh.]

AI: What a stupid question.

JSB: [Looking around.] This is very nice; is this a room in a church?

AI: What do you mean "in a church"?

JSB: Well, Maestro, you are, as far as I know, an organist. And organists...

AI: Ah, I understand you. No, I give concerts.

JSB: In church?

AI: No, at the conservatory.

JSB: Who listens to them?

AI: The public.

JSB: And they pay money?

AI: Of course!

JSB: How can you be happy Maestro if you don't play in church? And don't compose chorales every day?

AI: Maestro, you have genius chorales!

attempt to warn the conductor of the error make for a dramatic and humorous climax. Sima, of course, pulls off the unexpected transposition with aplomb. 
JSB: Yes, but I always dreamed about something else. All my life I wanted to compose a ... well, what do you think?

AI: An opera?

JSB: An operetta, as I think you call it! I had a great subject. If you can understand, a duke, passing by a river, sees a lovely shepherdess. I don't remember how it went after that, but it was very funny. [Laughs heartily.] Very, very funny! [AI laughs along nervously.]

AI: Maestro, of course, if you had composed it, it would have been genius. But that which is composed in this genre nowadays is terrible. You know, my heart bleeds. [Sits and plays an excerpt from Mukhin's operetta.]

JSB: That's not bad, not bad. No, it's ... good, even talented.

AI: No, one cannot even call this music! [Bach offers AI some snuff.]

JSB: Why not? [Bach snorts snuff into one nostril.] It's music. [Snorts into other nostril.] Light music.

AI: No, I don't recognize light music. When I listen to serious music I want to stand and remove my hat.

JSB: You're some kind of ...

AI: Yes, music should make one cry. [He sneezes from the snuff as he says the word cry.]

JSB: Ah, my friend you are a sectarian. If you believe this, then all that will remain of music will be psalms and chorales. What nonsense! Remove your hat?! You are a sectarian. Surely you can understand that people need all music, that which makes them cry, and that which makes them laugh. It only needs to be talented. It must be tal ... en ... ted.

AI: Maestro, maestro, my head is going in circles.

JSB: Don't be so impatient. Don't make idols out of music. Don't be so stubborn.

AI: Am I ... stubborn?

JSB: As a jackass!

Not his love for his daughter nor the opinions of his colleagues can convince Anton Ivanovich that he is stubborn and impatient, and that he has overly fetishized "serious" music. No, only the words of Bach himself persuade Anton Ivanovich that light music should have an important place in musical culture. Much to Anton Ivanovich's surprise, Bach-who, with a snuffbox in hand, appears here as the "jolly fat man" Andrey Apollonovich described in their earlier exchange-tells Anton Ivanovich that he himself also had wanted to compose an operetta, since people need music to make them cry and to make them laugh. ${ }^{22}$ For Bach, like for Mukhin, the most crucial aspect of any music, regardless of style or genre, is that it be "talented." Anton Ivanovich finally accepts that he has been an obstinate jackass only when Bach calls him that. After Bach has returned to his painting Anton Ivanovich demonstrates how he has been transformed by accepting the union of Mukhin and Sima and agreeing to perform the solo organ part in Mukhin's new symphonic poem, the premiere of which ends the film (Example 4).

${ }^{22}$ Ivanovsky noted that originally he "wanted to put a mug of beer in Bach's hand, but limited it to a snuffbox." Aleksandr Viktorovich Ivanovskiy, Vospominaniya kinorezhissera [Memoirs of a Film Director] (Moscow: Iskusstvo, 1967$), 244$. 


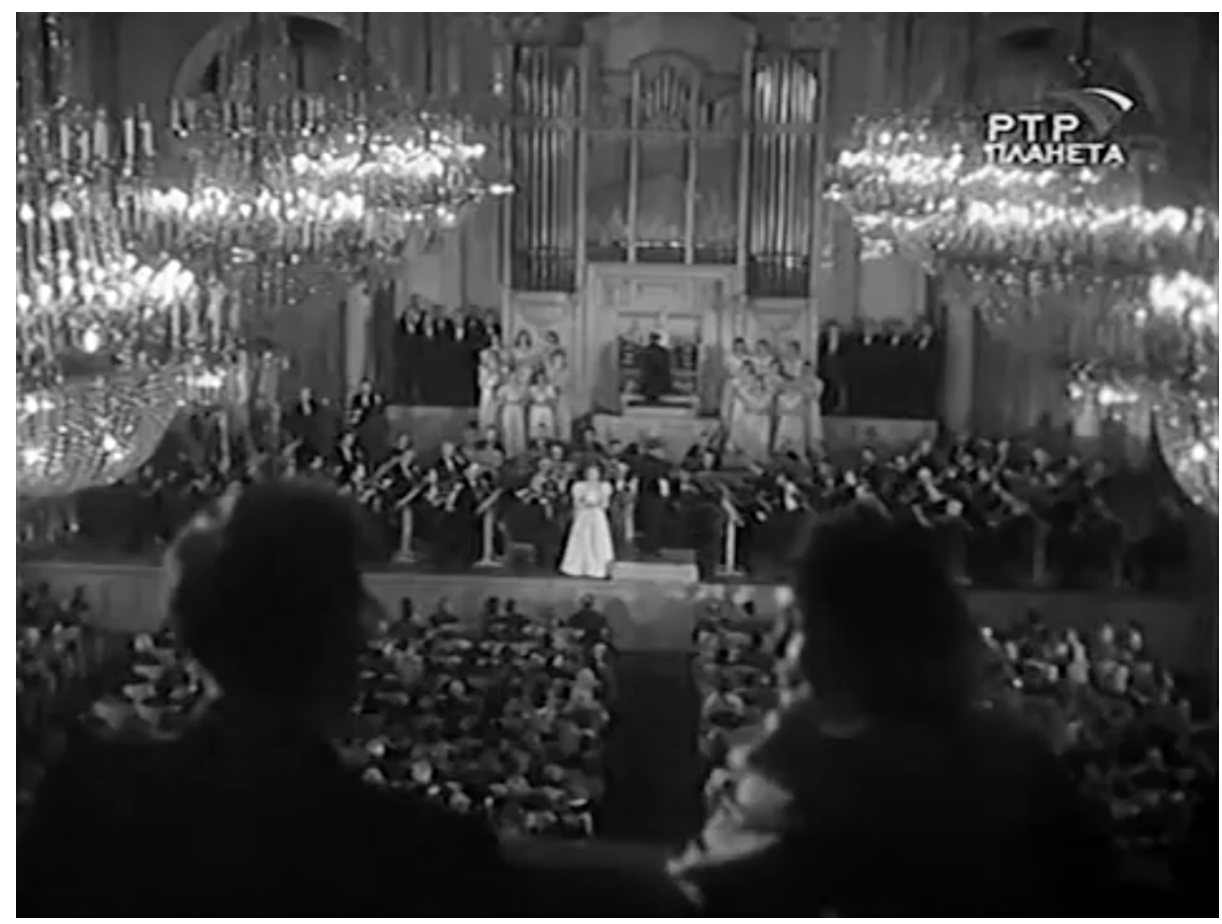

Example 4: The Premiere of Mukhin's Symphonic Poem

See video: http://dx.doi.org/10.3998/mp.9460447.0012.201

Though we hear less than three minutes of this work, it clear that it is meant to represent the serious side of Mukhin's style. The instrumentation (organ solo, vocal soloist, chorus, and full orchestra), the mostly tonal and predictable harmonic language, a text about the joys of labor and freedom, transparent textures, and grandiosity of utterance fit very much into the mold of large-scale Soviet Socialist Realist vocal-symphonic works of the period. ${ }^{23}$ Marina Frolova-Walker has shown that while not all works of this nature were equally successful, they nevertheless attempted to fulfill a new demand for works that clearly, if ritualistically and "boringly," embodied the tenets of Socialist Realism. ${ }^{24}$ As Frolova-Walker argues, such works are today often dismissed by Russian and Western commentators as aesthetic failures, but this says more about current aesthetic criteria than about the sincerity of the composers' efforts at the time to meet a particular need. Indeed, Gennady Pozhidayev recounts how Kabalevsky struggled even with the short excerpt of Mukhin's symphonic poem: "[Kabalevsky] also had to write for the hero of the film a 'short piece' of serious music with chorus and organ. A fragment-the final section of this work-ends the film. Recently, while again watching this old film ... Kabalevsky, remembering the past, smiled and said: 'It was terribly difficult to write the final non-existent work!'”25

Thus, the film's climactic moments-Anton Ivanovich's conversation with Bach and the premiere of Mukhin's cantata-are both staged as "realistically" as possible. This is especially apparent, I argue, in

\footnotetext{
${ }^{23}$ To cite only several others composed by the time of AIS and a few of their antecedents: Shostakovich's Second ("To October," 1927) and Third ("The First of May," 1930) Symphonies; Prokofiev's Cantata for the Twentieth Anniversary of the October Revolution (1937), Alexander Nevsky Cantata (1939), and Zdravitsa ("Hail to Stalin," 1939); Vissarion Shebalin's "Lenin" Symphony, op. 16 (1931); Aram Khachaturyan's "Poem on Stalin/Song of the Ashugh," (1938); and Kabalevsky's own Poem of Struggle, op. 12 (1930), Parade of Youth, op. 31 (1941), and Three Vocal Monologues for Voice and Orchestra, op. 33 (1941).

${ }^{24}$ Marina Frolova-Walker, "Stalin and the Art of Boredom," Twentieth-Century Music 1, no. 1 (2004): 101-24, https://doi.org/10.1017/S1478572204000088.

${ }^{25}$ G[ennadiy Alekseyevich] Pozhidayev, Dmitriy Kabalevskiy (Kiev: Muzichna Ukraïna, 1984), 65.
} 
Anton Ivanovich's dream sequence in which two musicians converse about music, but there is no nondiegetic (or diegetic) musical accompaniment. Neither the transition into or out of the dream world nor the dream state itself are marked off in any musical way, as would be de rigueur in the film musical and is often found in similar scenarios in narrative films. ${ }^{26}$ Ivanovsky himself noted that this scene was purposefully "staged in realistic, even in everyday colors." 27 Similarly, Mukhin's symphonic poem could have been taken straight out of a Soviet concert hall. This focus on "realism," including the choice of Bach as the symbol of one truth (the superiority of "serious" music), but messenger of another (taking all music, including light music, seriously), reflects debates about the development of Soviet musical tastes during the 1930s, in particular about the merits of serious and light music and about the place of the Germanic heritage within Soviet musical culture.

\section{High or Low? Russian or Not?}

The fortunes of light, or popular, music had vacillated wildly in Soviet Russia throughout the 1920s and 30s. ${ }^{28}$ It had found wide popularity in the 1920s under Lenin's New Economic Policy, when a partial free-market economy allowed Western cultural products, like jazz and Hollywood films, to reach Russian consumers. But a radical leftist turn came later in the decade, when the Russian Association of Proletarian Musicians (RAPM) condemned jazz (and virtually all art music not composed by Beethoven or Musorgsky) as improperly bourgeois and dangerous for the Soviet listener. ${ }^{29}$ With the dissolution of all such leftist organization by Central Committee decree in April 1932, Western-influenced popular music began to hesitantly flourish again, though the shape it took vis-à-vis the newly proclaimed artistic method of Socialist Realism in 1934 remained controversial throughout the decade (and beyond). Just like Anton Ivanovich, some critics and composers did not even want to recognize light music as music. At the same time, others argued vehemently that the tenets of Socialist Realism demanded the particular development of Soviet light music. As Simo Mikkonen has written,

many established composers jealously guarded traditional genres as the only authentic area of music. ... This question is closely related to the nature of music, whether the categories of "high" and "low" music were valid or not. ... Some were even ready to regard popularity as the meter of a composition's value.... In [one critic's] view, the elitism of musical experts was the greatest of barriers to music serving Socialist construction. It seems that at least some reputed composers were ready to admit that publicity mattered. ${ }^{30}$

This even played out in the national press. In January of 1936 Pravda famously denounced Shostakovich's Lady Macbeth for sounding, among other things, like jazz, but in December of that same year it suddenly defended jazz against attacks made by critics in Izvestiya. ${ }^{31}$ Invoking the power of the Party, Pravda "won" in the end: "We need jazz too, and will not allow bourgeois aesthetes and their protectors to

\footnotetext{
${ }^{26}$ The transitions into and out of the dream are only indicated visually, by a zoom into the painting, paired with cross fade from the portrait to the "real" man, and vice versa.

${ }^{27}$ Ivanovskiy, Vospominaniya kinorezhissera, 244.

${ }^{28}$ See, for example, S. Frederick Starr, Red and Hot: The Fate of Fazz in the Soviet Union, 1917-1991, 2nd ed. (New York: Limelight, 1994).

${ }^{29}$ See Amy Nelson, “The Struggle for Proletarian Music: RAPM and the Cultural Revolution,” Slavic Review 59, no. 1 (2000): 101-32, https://doi.org/10.2307/2696906.

${ }^{30}$ Simo Mikkonen, Music and Power in the Soviet 1930s: A History of Composers' Bureaucracy (Lewiston, NY: Edwin Mellen Press, 2009), 202.

${ }^{31}$ For a summary of this debate, see Starr, Red and Hot, 163-69.
} 
drive it from the stage," noted one commentator. "It is hopeless to defend positions which are against the line of the Party and of the government," wrote another a few days later. ${ }^{32}$ Nikolai Chelyapov, the Chairman of the Moscow Composers' Union, argued that too many critics had "erroneously juxtaposed jazz with symphony. He stated that there was good jazz and good symphonic music, which were in no way mutually exclusive. People expected light music from Soviet composers and this demand had to be satisfied." ${ }_{33}$ Eventually, composers of light music were admitted to the Composers' Unions, where indepth debates were conducted about the place of light music in Soviet musical culture. In one such discussion organized by the St. Petersburg Composers' Union in January 1937, many of the major names in Soviet light music argued about the role of jazz in Soviet musical culture. ${ }^{34}$ And while no concrete plan of action was reached that day, there was a wide consensus that serious and light music could, and should, both be central elements of Soviet musical culture. Dunayevsky, for example, stated boldly that a specifically Soviet jazz style "does not exist," but that by looking to Western art music and any number of other sources, there was hope for light music. ${ }^{35}$ At least one contemporary critic of AIS agreed:

What is convincing in this film? The cheerful story itself? But it hangs in the air, since the false assumption is made that [Anton Ivanovich] Voronov's error is upsetting to the living. No, it is not yet upsetting. The Fifth Symphony and Quintet of Shostakovich, the concerto of Khachaturyan; it is all of this that that has caused the organist Voronov, together with the great masses of Soviet listeners, to be excited-it is this that can convince. The works in operetta that would convince with such power do not yet exist. The theme of the script hangs in the air because currently it does not have organic contact with life. In Soviet art "heavy" and "light" genres are not opposed. And they should not be opposed. What is necessary is to achieve the best in these as well as in others. And it is not this about which Anton Ivanovich is upset ... ${ }^{36}$

But, writing nearly 30 years later, the Soviet film historian Rostislav Yurenev believed that AIS did eventually achieve this goal: it "gave the correct answer to this 'eternal' question. Serious and light music can both be good if written talentedly, in good faith, masterfully and if it is played relevant to the time, place, and mood of the listeners." ${ }^{37}$ My purpose here is not to argue whether or not the boundaries between light and serious music were ever effectively or properly broken down, but rather to highlight how this film tackled contemporary concerns about this dichotomy, and did so in a more self-consciously realistic manner.

It is interesting to note also that the composers that Anton Ivanovich elevates throughout the film are all non-Russians. It is interesting to note that the composers that Anton Ivonovich elevates throughout the film are all non-Russians: Bach, of course, but also Beethoven (though only his serious, noncommissioned compositions), Handel, Gluck, and Haydn. Even Mukhin, who, as we have seen, is ostensibly the defendant and representative of light music in the film, is untroubled by the invocation of Beethoven and Strauss as his teachers (along with Rimsky-Korsakov). And, as we will see below, he also defends attacks on Chopin, Chaikovsky, Glinka, Berlioz, Borodin, and Rossini. So while several Russian

\footnotetext{
${ }^{32}$ Cited in Starr, 168.

${ }^{33}$ Cited in Mikkonen, Music and Power in the Soviet 1930s, 203.

${ }^{34}$ See, for example, "Stenograficheskiy otchet, Leningradskiy Soyuz Sovetskikh Kompozitorov, Diskussiya o dzhaze (18-go Yanvarya 1937 g.) [Verbatim Report, Leningrad Union of Soviet Composers, Discussion about jazz (18 January 1937)],"

RGALI f. 2062, op. 1, yed. khr. 331. See also the discussion of this report in Kupfer, "Volga-Volga," 567-70.

${ }^{35}$ Cited in Kupfer, 570.

${ }^{36}$ M[oisey Osipovich] Yankovskiy, "Pochemu serditsya Anton Ivanovich? [Why is Anton Ivanovich Upset?]," Kino, January 24, 1941. The Khachaturyan reference is presumably to the Violin Concerto, which was completed and premiered in 1940.

${ }^{37}$ Rostislav Nikolayevich Yurenev, Sovetskaya kinokomediya (Moscow: Nauka, 1964), 306-7.
} 
composers are invoked as examples of "good" music, they are at least equal, if not secondary (as in Anton Ivanovich's case) to western European "masters."

Like the attempts to reconcile light and serious music in the 1930s, this state of affairs also had precedent in the contemporary Soviet musical aesthetics, as Pauline Fairclough has shown in her study of orchestral repertory and reception of classical music in the early Soviet years. She notes that "between approximately 1926 and 1936 ... it was Western rather than Russian classics that held sway: Bach, Handel, Mozart and Beethoven were the icons of the mid to late 1930s, and their replacement with Chaykovskiy, the kuchka and Glinka took place surprisingly late in the decade." ${ }^{38}$ Bach, in particular, was heavily lauded, despite his dedication to sacred music. His star rose in part because of a reevaluation of his work that accompanied the celebrations of the 250th anniversary of his (and Handel's) birth in 1935 . In these efforts, both composers were characterized as products of their time who could not escape their historical conditions (i.e., the requirement to compose sacred music), but whose music was in actuality far more about "human" values and struggles than anything specifically religious: "The real essence of [Bach's music] was profoundly human and emotional-the very opposite of "religious mysticism." 39 The musicologist Ivan Sollertinsky summarized the new view on Bach succinctly in 1935: "Like all the other great achievements of old European culture [Bach's music] belongs to the proletariat." ${ }^{40}$ What better way to achieve the goal to "make [Bach] contemporary" than to use him in AIS, quite literally, to resolve a contemporary musical "problem"? Though Bach is the focus of AIS, composers like Pergolesi, Mozart, and Beethoven were also reimagined and/or "pardoned" for having needed to succumb to the demands of the times and places in which they lived. ${ }^{41}$ Even such seemingly anti-Soviet works as the oratorios of Handel and the requiems of Verdi and Berlioz were subjected to major rebranding campaigns in order to highlight the "epic" and "monumental" qualities that could be useful to Soviet propagandists, even if it meant negating their true sacred subject matter. ${ }^{42}$ Ultimately, as Fairclough writes, the goal of all this revisionism was to enable the Soviet Union to maintain a semblance of internationalism and cosmopolitanism, and "to craft its image as inheritor supreme of Enlightenment values." 43

This focus on Western culture was also a reflection of the damage that had been done by RAPM on views of traditional Russian nationalist musical culture. Their rhetoric, in particular that the great musical heritage of the past (save for Beethoven and Musorgsky) was tainted by its bourgeois social and economic context, took time to defeat. Eventually, from 1937 onward, the sentiment of the infamous slogan that the Soviet arts should concern "the development of cultures national in form and socialist in content" led to a renewed emphasis on the Russian musical heritage, but it was not an overnight shift. ${ }^{44}$ As Fairclough writes, "Soviet musical culture was noticeably reluctant to relinquish its embrace of the eighteenth century; the high point of such performances was as late as 1938-40." ${ }^{45}$ For AIS to thus privilege Bach

\footnotetext{
${ }^{38}$ Pauline Fairclough, Classics for the Masses: Shaping Soviet Musical Identity under Lenin and Stalin (New Haven: Yale University Press, 2016), 6, https://doi.org/10.12987/yale/9780300217193.001.0001.

${ }^{39}$ Fairclough, 124.

${ }^{40}$ Cited in Fairclough, 124.

${ }^{41}$ Fairclough, 127-33.

${ }^{42}$ Fairclough, 120-23.

${ }^{43}$ Fairclough, 103. On this internationalism and cosmopolitanism, see also Katerina Clark, Moscow, the Fourth Rome: Stalinism, Cosmopolitanism, and the Evolution of Soviet Culture, 1931-1941 (Cambridge, MA: Harvard University Press, 2011), https://doi.org/10.4159/harvard.9780674062894.

${ }^{44}$ On the various aspects of this process, see Marina Frolova-Walker, Russian Music and Nationalism: From Glinka to Stalin (New Haven: Yale University Press, 2007), 301-55; Fairclough, Classics for the Masses, 140-71.

${ }^{45}$ Fairclough, Classics for the Masses, 120.
} 
over Glinka, or any member of the kuchka, as well as to thematize the juxtaposition and eventual reconciliation of serious and light music, reflected contemporary musical aesthetics.

\section{"Explosive" Formalism}

Not surprisingly for an entertainment film, though, references to specific Soviet practices or policies are nearly absent. The one such reference is made by Kibrik in a scene in which Kholodetskaya first previews a song she has commissioned from Kerosinov. "The issue at hand is his use of "folk" sources (Example 5).

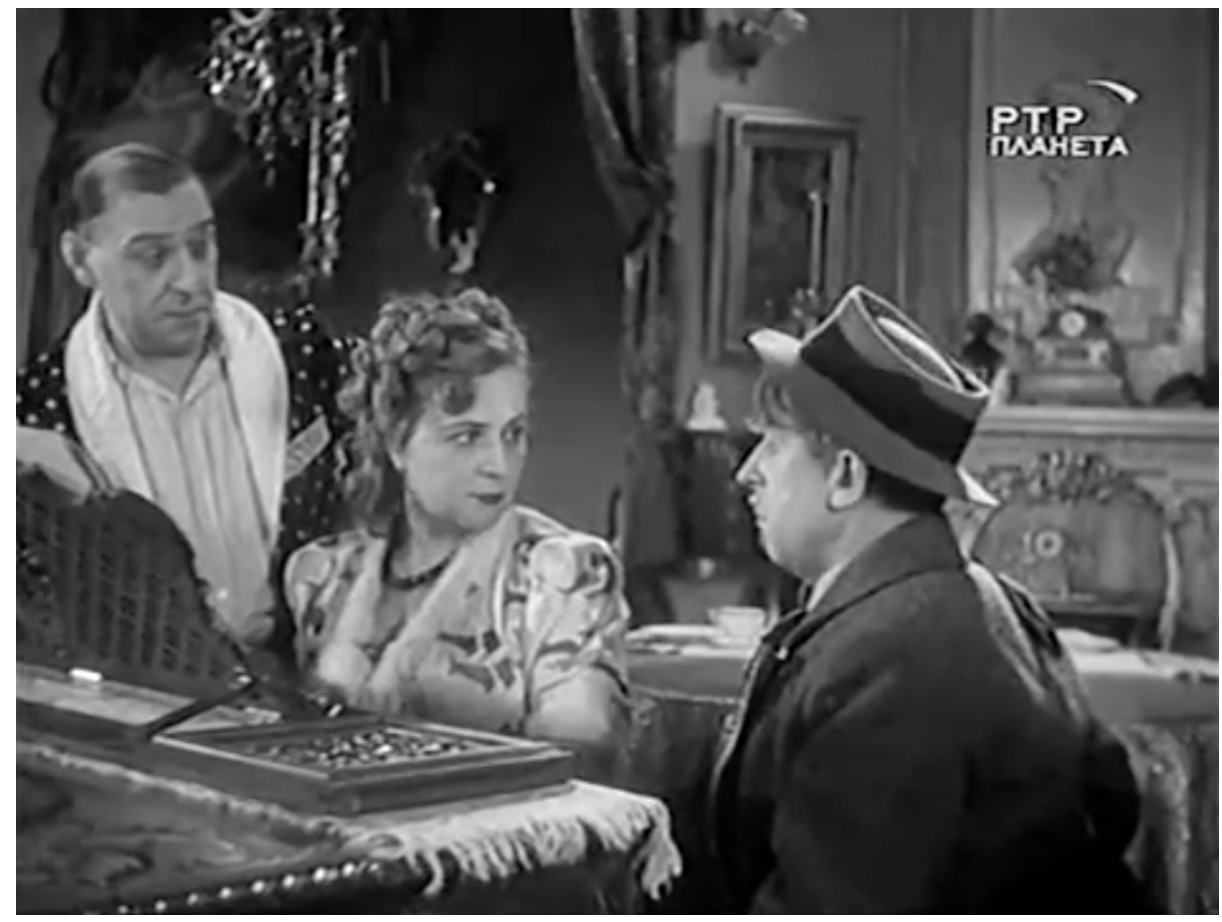

Example 5: Musical Theft

See video: http://dx.doi.org/10.3998/mp.9460447.0012.201

Kholodetskaya: So, did you bring the music ${ }^{37}$

Kerosinov: Yes, but ...

Kh: No buts! Give it to me.

$\mathrm{K}$ : You promised a down payment.

Kh: First show it to me.

K: Only in my hands. It's exactly what you requested: a "three-minute

number with dances." The audience will squeal and cry!

Kh: Kerosinov, give it to me.

K: First, 100 rubles.

Kh: First, I will play it.

K: If you play it, it'll be 300. Don't be stingy now-I know how much you don't like opening your purse!

Kh: What was that?! It appears that you don't trust me!

Kibrik: Calm down, calm down.

K: Kholodets, we have known each other for a while, and each time you need to pay, you start

\footnotetext{
${ }^{46}$ The scene was presumably added late in the shooting process, as it does not appear in the printed script of the film.

${ }^{47}$ I thank Olga Amelkina-Vera for help with translation of this scene.
} 
bawling. $^{48}$

Kh: You are so childish!

Kibrik: You promised 100, and he's a composer after all...

$\mathrm{Kh}$ : Absolutely everyone is against me!

[She reads the first lines of the text.]

"Nadyusha, remember the evening, and the happiness of our first encounter?

It intoxicates me like wine!”

Very cute.

Ki: Not bad.

[She sings it, accompanying herself at the piano, but stops suddenly.]

Kh: What is this?! What is this exactly?!

$\mathrm{K}$ : What do you mean what?

Kh: What do you mean what?! It continues:

"A big crocodile was walking down the street, It, it was green." 49

What is this exactly?

Ki: Why didn't you simply write down "In its mouth it held a piece of a blanket"?50

K: [playing dumb] What piece of blanket? Who was holding it? Nadyusha?

Ki: Kerosinov, stop playing dumb! This is a direct borrowing!

Kh: What "borrowing"?! [To Kerosinov] You simply took it and stole it!

K: Philistines! Have you never heard of the word "folklore"? A composer has full right to use this song as material, to weave it into his work.

Ki: Do you know my dear, why don't you tell all of this to the Composers' Union!

$\mathrm{Kh}$ : And now, give the money back!

K: Fine, I will correct it. That means two measures and no one will guess the difference. The audience will squeal and cry!

Kh: Not just two measures, not just two measures! Fix everything, from the beginning ... to the end!

While Kerosinov believes that his use of the comic urban song "A big crocodile walked along the street" is completely justified in the name of folklore, Kholodetskaya sees it simply as theft, suggesting not only that Kerosinov is unable to even write a simple melody of his own, but that he also does not understand what true folk music is. The scene is intended to be funny, to be sure, but unlike most of the humor in the film this is a more biting and sinister sarcasm: Kibrik's suggestion that Kerosinov take the matter to the Composers' Union, where, presumably, he would be set straight for violating the "rules" of Socialist Realism, reflects the ever-thinning margin for error that composers faced during the 1930s when

48 "Kholodets" is a nickname derived from her last name, but it is also a kind of Russian aspic.

${ }^{49}$ Here Kerosinov is quoting the text of a well-known contemporary comic urban song "Po ulitse xhodila bol'shaya krokodila" (A big crocodile walked along the street). The music for the song derives from a WWI-era march titled "Dni nashey zhizni" (Days of our Lives) by Lev Isaakovich Chernetsky.

${ }^{50}$ Kibrik here quotes the next verse, which concludes "And it thought it was a ham." 
it came to fulfilling the maxim that all art should be "national in form, socialist in content." As Marina Frolova-Walker has written about this period,

folk material ... provided a much-needed degree of safety. Without folk material, composers knew that there was only the narrowest stretch of dry land between "formalism" on the one side, and banality on the other. Both faults were equally open to condemnation, the former because it ignored the (supposed) needs of the people, the latter because it patronized and underestimated the people. But the use of folk music greatly decreased the likelihood that a composer would suffer either of these criticisms. ... [P] ronouncements began to appear in the press with threatening regularity, each time persuading more composers that it was in their interests to write music that was national in form, socialist in content. ${ }^{51}$

This summary of the historical context describes Kerosinov's situation eerily well. As this scene clearly shows, he does not understand true folklore, and thus his attempt at a folk-inspired song results in banality (which Kibrik and Kholodetskaya indeed find extremely patronizing) and condemnation.

Most damning, however, is that he is clearly to be taken as a "formalist" composer, which becomes evident later in the film when Dina, Sima's sister, asks him about the new symphony he is working on (Example 6).

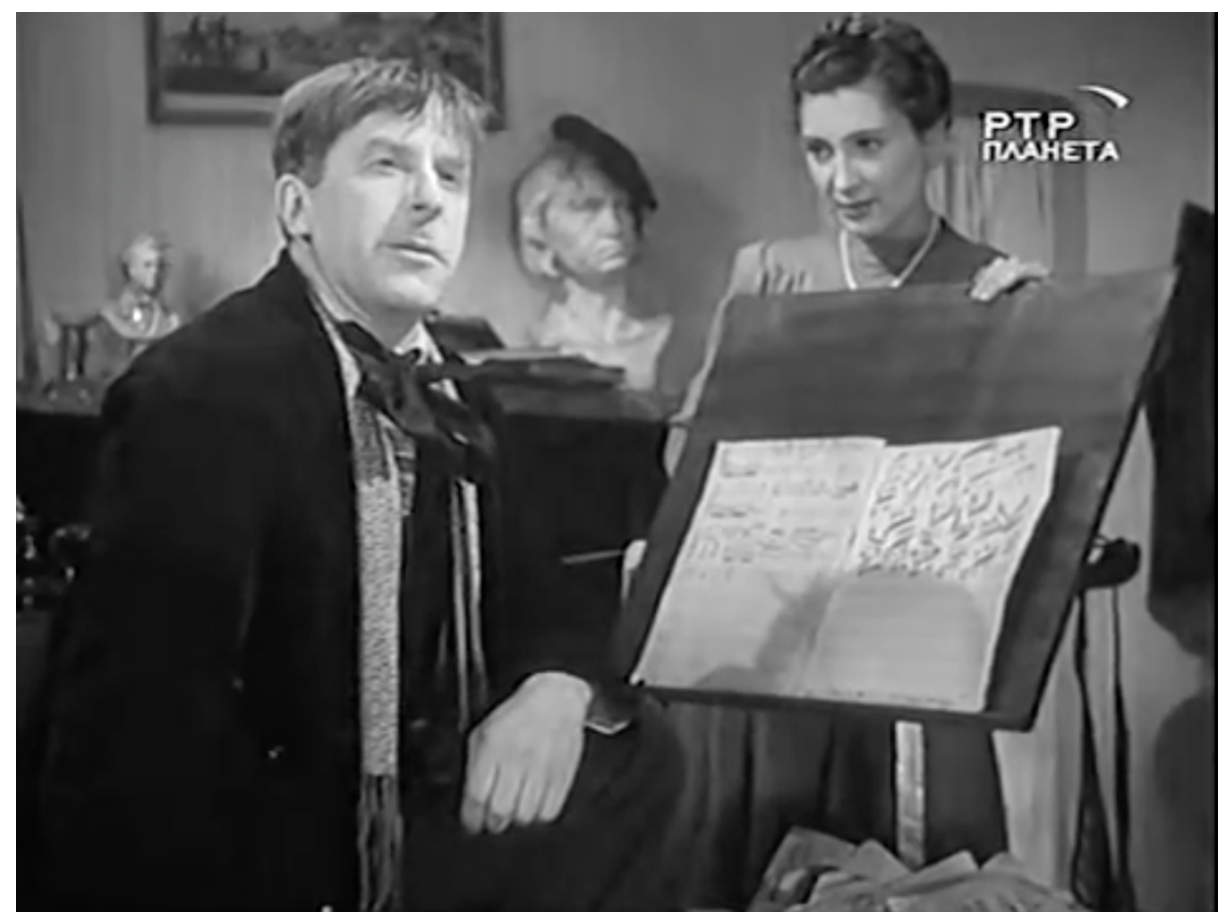

Example 6: Kerosinov on his Symphony

See video: http://dx.doi.org/10.3998/mp.9460447.0012.201

[Kerosinov sings a grotesque flourish.]

Dina: Kerosinov, why do you call the movements of your symphony paroxysms?

"Physiological Symphony in Four Paroxysms." Why not simply call them-first movement, second movement ...?

Kerosinov: In to order understand, you need to listen to it. And not just once, but 30 times!

[He sings the flourish again.]

\footnotetext{
${ }^{51}$ Frolova-Walker, Russian Music and Nationalism, 316.
} 
D: Oh, how I would love to hear it.

K: In two years, maybe, I can play you the first version.

D: Kerosinov, you are a unique person.

$\mathrm{K}$ : Yes. Of course. I could write commissions, I could become rich, or, as they say, famous!

[He smiles proudly.] But right now I am a burden on everyone, a stranger to all, a

little man not known to anyone.

D: Is it bad for you living here with us?

$\mathrm{K}$ : Yes, it's bad for me here.

D: But why?

K: Because I am eating someone else's bread. And you have no idea how bitter someone else's bread is for an artist.

D: You're not a stranger, Kerosinov. We love you like one of our own. You know how papa [i.e., Anton Ivanovich] loves you. How when you tried to leave the last time, he almost fell ill!

K: Of course, Anton Ivanovich loves me. But your little sister Simochka-You think I don't know that she calls me Kerosin Benzinov and my symphony the "zoological"?

D: Kerosinov! Think about what you're saying! Sima is a frivolous girl. She's just joking.

$\mathrm{K}$ : What, are you joking? She laughs at Kerosinov! [He throws his manuscript on the floor.] Trample it with your feet! [He lays down in bed, Dina walks over to him.]

D: Calm down. We won't speak about this.

K: [He sits up when he hears Sima in the next room singing Handel's "Lascia ch'io pianga" from Rinaldo.] What is that? Again a concert? Again this Gluck, Bach, all of this closeminded, antiquated rubbish!

D: Ok, fine, you don't like the classics. But do you also not like new composers?

$\mathrm{K}$ : Music should not be composed [sochinyat'], but invented [izobretat']. [He sings the grotesque flourish once more.]

With a "Physiological Symphony" that has "paroxysms" instead of movements (and that he has been working on for nine years and has burned 4,000 pages of fragments of already, as we have learned earlier in the film), a dismissal of those who compose "on commission," a fiercely individualistic artistic demeanor, and the view that music must not be "composed" (sochinyat'), but "invented" (izobretat'), Kerosinov represents a third stream in the debate about the validity of musical styles and genres: he is a thinly veiled caricature of the formalist composer. ${ }^{52}$ This too, reflects real world Soviet musical aesthetics of the time. As Fairclough has written, "What happened after 1936 was that modernism and internationalism became regarded as entirely separate entities: modernism—now dubbed 'formalism,' or music that was considered complex, atonal or jazz-inflected—was to be judged inappropriate for Soviet audiences and misleading for the Soviet composers who were supposed to serve them, but internationalism was a marker of cultural esteem, of the Soviet Union's right to participate on the world stage."53 Kerosinov's money-grubbing, stark individuality, ego, mysteriousness, reluctance to let anyone hear his music, and obscure musical style all point to an aesthetic that is anti-popular and anti-intelligibility; it is, in short, anti-Socialist Realist. His repeated "singing" of a grotesque gesture from the symphony, moreover, comically likens his music to

\footnotetext{
${ }^{52}$ On this interpretation, see also Marina Raku, Muzikkal'naya klassika v mifotvorchestve sovetskoy epokhi [Musical Classicism in the Mythology of the Soviet Epoch] (Moscow: Novoye literaturnoye obozrenie, 2014), 648-49, Google Play e-book, https://play.google.com/store/books/details?id=LcTSBgAAQBAJ\&hl=en (accessed June 1, 2018); Tatiana K. Egorova, Soviet Film Music: An Historical Survey, trans. Tatiana A. Ganf and Natalia A. Egunova (Amsterdam: Overseas Publishers Association, 1997), 49-50. Though Shostakovich had been rehabilitated by 1941, Kerosinov's character can perhaps be understood as a parody of his supposed youthful formalist digressions, with the "paroxysms" referring to his 1927 set of atonal piano miniatures called "Aphorisms."

${ }^{53}$ Fairclough, Classics for the Masses, 118.
} 
slapstick noise. And that he fails to recognize the composer of the piece Sima is singing, but yet dismisses it all the same, underscores his hypocrisy. In a later scene, we learn even more about his true beliefs and character (Example 7).

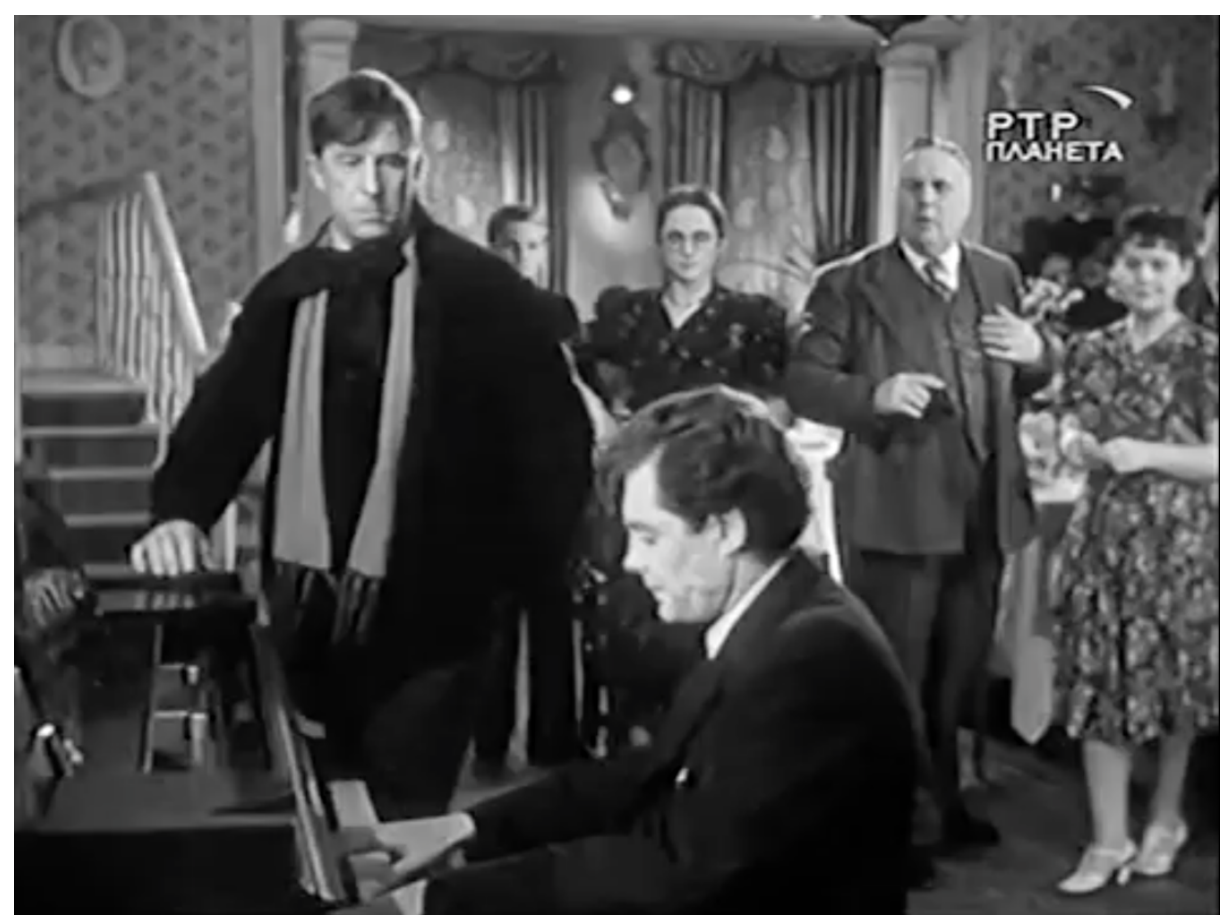

Example 7: Mukhin and Kerosinov on Musical Taste

See video: http://dx.doi.org/10.3998/mp.9460447.0012.201

[Kerosinov and Mukhin discuss the operetta after a performance of some excerpts at Anton Ivanovich's home.]

Kerosinov: Yes, yes, I heard it. It was Chopin, Chaikovsky, Grieg, with their waltzes, polkas, and mazurkas. All this musical caramel should be swept away with a broom!

Mukhin: Be quiet! Fine, now, when you abused me, I was quiet. But if you deign to suggest to sweep away Chopin and Chaikovsky. Well, what's left? You haven't finished your own physiological symphony yet!

$\mathrm{K}:$ Bach is left, and in part Haydn.

M: And Glinka?

$\mathrm{K}$ : Well, that should go into the trash!

M: Fine. And Beethoven!

$\mathrm{K}$ : That too, that too.

M: Fine. And ... Berlioz? Borodin? Rossini?

$\mathrm{K}$ : All, all into the trash!

M: Fine, what about this? [Mukhin sits at the piano and plays the same Bach-like excerpt

Anton Ivanovich had used to demonstrate serious music to Andrey Apollonovich earlier in the film.]

K: Gibberish! Into the trash!

M: No, no. [Addressing the others in the rooms.] You hear what he says! [Turning back to Kerosinov.] For your information, that was Bach. Bach! You are a windbag and an ignoramus.

Again, Kerosinov is made out to be a hypocrite: he suddenly thinks Bach is worth saving after having denounced him to Dina as antiquated rubbish, but cannot even recognize his music when Mukhin plays it 
for him. ${ }^{54}$ Furthermore, he believes that virtually all other composers, including Russians, are worthless. $\mathrm{He}$ is, in this way, the exact foil to Mukhin's tolerant views.

Kerosinov's character thus represents a third component in the battle of musical styles: serious vs. light vs. formalist. In light of the historical context, Kerosinov's character, while perhaps the funniest of all, is also, the most incendiary, as it were, because while serious and light music were eventually both officially sanctioned, the charge of formalism remained for decades a feared tool for punishment of artists of all types. In making light of formalism, AIS thus reminds us in a sinister way that while the realm of acceptable Soviet musical practice expanded throughout the 1930s to include light music, it was nevertheless still circumscribed and excluded a great deal. The one silver lining, perhaps, is that Kerosinov is eventually allowed to participate in the triumphant performance of Mukhin's symphonic poem. He is not, in other words, excised from the musical community, but is "relegated" to smashing the cymbal (which he does gleefully) - the closest he comes to realizing the "noise" of his own style. In reality, his experimental musical sound world is silenced. Reversing Kerosinov's quip to Mukhin regarding the value

of classical composers, Marina Raku writes that "the film clearly shows that it was the victorious Soviet culture that sent the avant-garde 'into the trash." "'55

\section{The "Real" Composer}

Within the context of the film, then, Kerosinov's and Anton Ivanovich's sectarian views serve as the negative foils to Mukhin's democratic musical tastes. But there is yet another composer in, or rather behind, this film, whose name has thus far gone largely unmentioned: the actual composer of Mukhin's operetta and symphonic poem, namely, Kabalevsky. ${ }^{56}$ Like Mukhin, Kabalevsky himself believed very much in breaking down the barriers between light and serious music. He made a point of this especially in his work with children, whom he believed should not be taught to hierarchize different kinds of music. He explained this in detail in his 1972 book, About the Three Whales and Many Other Things: A Book on Music, using $A I S$ to make his point:

After all, in speaking with Anton Ivanovich, [Bach] spoke with many millions of moviegoers, helping them to sort out the many complex issues of music that we confront constantly, but finding the right answer to them is not so simple as it sometimes seems.... But the main thing is that any music-both the most serious and the lightest-must first of all be good music. Between light music and serious music there is no wall and no impassable abyss. They not only exist side by side, but they often coalesce with each other and even pass into the other, just as joy and grief, laughter and tears coalesce and pass into one another in life.... In a word, the "light" and the "serious" are intertwined in music as they are in life. And if there is an impassable chasm and wall in music, then we should not look for them between "light" and "serious," but between good and bad. And one should never think that serious music is music of the "first class," and light music is "second-class" music. Both must be "first-class" ${ }^{57}$

\footnotetext{
${ }^{54}$ Or music meant to sound like Bach: see n. 20 above.

${ }^{55}$ Raku, Muzïkal'naya klassika, 649.

${ }^{56}$ The only pieces from his score that were published are both from "Mukhin's" operetta: Pesenka (foks-trot 'Kogda lunu sprosili...') [Ditty (fox-trot 'When we asked the moon...')] (Moscow: Muzikal'niy fond SSSR, 1945) and Val's: Iz kinofil'ma "Anton Ivanovich serditsya," dlya golosa s $f$-p [Waltz: From the film Anton Ivanovich serditsya, for voice with piano] (Moscow: Muzikal'niy fond SSSR, 1945). The latter was also recorded.

${ }^{57}$ Dm [itriy] Kabalevskiy, Pro tryokh kitov i pro mnogoye drugoye: Knizhka o muzïke [About the Three Whales and Many Other Things: A Book on Music] (Moscow: Detskaya literatura, 1972), 217-18. As an attempt to lend a more grounded historical
} 
These are virtually the same words that Mukhin utters in the film (compare Example 2b above). But lest we believe that Kabalevsky was attempting in his later years to rewrite his past by making life imitate art, by the time he had scored AIS in 1941, he had already composed a number of light works, including many for children, such the music for Mark Daniel's 1937 children's play The Inventor and the Comedians (the source of his famous "Comedians" Suite, op. 26), as well as several films scores. Writing in the early 1940s, Gerald Abraham noted that Kabalevsky's style to that point was marked by a certain directness: "transparency, not to say simplicity, of texture is characteristic of Kabalevsky's music in general. His talent is essentially lyrical and he sets his lyrical outpourings against backgrounds that never threaten to overwhelm them." ${ }^{58}$ Indeed, though he experimented with a more dissonant language early in his career, from the mid-1930s on Kabalevsky generally fostered a readily accessible language, taking the tenets of Socialist Realism seriously (which translated also into a long career as a musical bureaucrat). ${ }^{59}$ Levon Hakobian has noted that this style lent itself particularly well to writing film music, citing AIS as a prime example: "Thanks to his skill in inventing light and pleasant melodies, he became a fashionable and fecund composer of incidental music (the score for the musical film Anton Ivanovich Is [Upset] ... being his best known achievement in this field), as well as music for children and youth." ${ }^{60}$

With this aesthetic outlook, it was strange (and ironic given the plot of AIS) that Kabalevksy had at first been included in the list of formalist composers singled out by Zhdanov in his 1948 Resolution on Music. ${ }^{61}$ After his name was removed (due to some fortunate personal connections), Kabalevsky decided "to strike a repentant pose. ... He showed his good will by composing an easy-going Violin Concerto ... eschewing both high intellectual and technical demands. [The composer Nikolai] Myaskovsky humorously referred to it as a 'children's concerto,' judging it ... to be 'lightweight, but not at all bad."”62 Through these assessments of Kabalevsky's oeuvre we see that he was usually lauded for his gifts of craft, lyricism, and accessibility. He was, in other words, generally judged, like Mukhin, to be sincere and largely successful in achieving his stated goals of balancing and interweaving serious and light music. And perhaps in an instance of art imitating art, Kabalevsky composed an operetta of his own, titled The Spring Sings, op. 58 (1957), in which one of the female leads is named Sima (Mukhin's operetta in AIS is called Spring Song). ${ }^{63}$

\section{Conclusion}

In her 1965 review of Kabalevsky's film music, Dina Daragan claims that "the music written ... for

\footnotetext{
basis to Bach's claim in the film that he had also wanted to compose an operetta, in this section of the book Kabalevsky also discusses in detail Bach's Coffee Cantata, BWV 211 as an example of his ability to compose also popular secular works.

${ }^{58}$ Gerald Abraham, "Dmitry Kabalevsky," in Eight Soviet Composers (London: Oxford University Press, 1943$), 73$.

${ }^{59}$ See Richard Taruskin, "Two Serendipities: Keynoting a Conference, 'Music and Power," in Russian Music at Home and Abroad: New Essays (Berkeley: University of California Press, 2016), 303-31, https://doi.org/10.1525/im.2016.33.3.401.

${ }^{60}$ Levon Hakobian, Music of the Soviet Age, 1917-1987 (Stockholm: Melos Music Literature, 1998), 148.

${ }^{61}$ The inclusion was largely due to his "modernist" 24 Preludes for Piano, op. 38 (1944). For more on this see Taruskin, "Two Serendipities," 320; Marina Frolova-Walker, Stalin's Music Prize: Soviet Culture and Politics (New Haven: Yale University Press, 2016), 153-54, https://doi.org/10.12987/yale/9780300208849.001.0001.

${ }^{62}$ Frolova-Walker, Stalin's Music Prize, 153-54.

${ }^{63}$ However, a comparison of the brief excerpts of Spring Song heard in AIS with The Spring Sings reveals no readily discernable borrowings, nor do any of the commentators on the film's music or on Kabalevsky cite any connection between the two either. See Dmitriy Kabalevskiy, Vesna poyot (operetta v 3 aktakh) [The Spring Sings (operetta in 3 acts)], libretto by Ts. Solodar', [piano vocal score] (Moscow: Sovetskiy kompozitor, 1959). A 1967 television adaptation of The Spring Sings can be viewed at https://ok.ru/video/269582076509 (accessed May 31, 2018).
} 
[AIS] received wide fame." ${ }^{\prime 4}$ She does not provide evidence for this assertion, however, and a survey of reviews and scholarship on the film as well as of Kabalevsky's music do not bear out a widespread critical impact of the film, whether at the time of its premiere or in the following decades. ${ }^{65}$ Much of this probably has to do with the fact that the film was released on August 29, 1941, just weeks after the Nazi invasion of the Soviet Union, by which time the focus of the nation (and the film industry) had shifted away from everyday escapist entertainment. In Leningrad, the film's release coincided with the initial bombardment of the city ahead of the eventual blockade, which commenced on September 8. In fact, as Olga Berggol'ts famously noted in her diary about the blockade, posters for AIS remained hanging from lampposts around the city throughout the horror of those years (see Figure 1). She describes the odd effect this created as the blockade worsened:

Whoever walked along Nevsky [Prospekt], no matter how many times he raised his eyes, he always saw these posters, which, while the war, attack, blockade and calamity of the city were unfolding, turned into a kind of warning, a reminder, [and] a loud reproach: "Nevertheless Anton Ivanovich Is Upset!" And in our imagination there involuntarily emerged some real, living person, [who was] very kind, who did not understand everything, [who] direly wished people happiness and [who] kindly, broken-heartedly, got angry at people for all the unnecessary, ridiculous, and terrible suffering, to which they all for some reason subjected themselves. After the shelling the corpses of mutilated citizens were dragged under the lampposts. Dystrophic people hugged the lampposts, trying to stay on their feet, and slowly slid down toward the pedestals such that they were no longer standing ... Anton Ivanovich was upset. Oh, how he became upset, sorrowfully became upset at all of this! And how ashamed one sometimes became in front of Anton Ivanovich-the man. One wanted to say for oneself and for all the people of the world: "Anton Ivanovich, dear, kind Anton Ivanovich, don't be upset with us! We are not to blame. We are still good people. We will recover somehow. We'll fix this mess. We will live like humans." ${ }^{66}$

\footnotetext{
${ }^{64}$ Daragan, Kinomuzïka D. Kabalevskogo, 38.

${ }^{65}$ Compared to films from even a year earlier, AIS was reviewed far less. The Annotated Catalog of Soviet Film, for example, lists only six articles about the film, and none in Pravda, Izvestiya, Literaturnaya gazeta, or Iskusstvo kino. This can be compared with the entries in the catalog for Ivanovsky's previous film A Musical Story, released 24 October 1940, which lists nine articles and Aleksandrov's The Radiant Path, released 8 October 1940, which lists 20. See Macheret and Glagoleva, Sovetskiye khudozhestvennïye fil'mï, 2:237, 243, 252. In addition, the film is not mentioned at all or receives only the most cursory treatment in much of the scholarship on Kabalevsky, whether in Russian or English. See Ye[lena] Grosheva, $D$. Kabalevskiy (Moscow: Muzikal'niy fond SSSR, 1956); G[eorgiy] Abramovskiy, D. Kabalevskiy (Moscow: Sovetskiy kompozitor, 1960); L[ev Vasil'yevich] Danilevich, Tvorchestvo D. B. Kabalevskogo [The Oeuvre of D. B. Kabalevsky] (Moscow: Sovetskiy kompozitor, 1963); R[aisa Vladimirovna] Glezer, Dmitriy Borisovich Kabalevskiy (Moscow: Sovetskiy kompozitor, 1969); Grigoriy Roshal', "Radostnaya kinosyuita [Joyful Film Suite]," in Dmitriy Kabalevskiy: Tvorcheskie vstrechi, ocherki, pis'ma [Dmitry Kabalevsky: Creative Encounters, Essays, Letters] (Moscow: Sovetskiy kompozitor, 1974), 15-27; Abraham, "Dmitry Kabalevsky"; S. D. Krebs, "Dmitri Kabalevsky," in Soviet Composers and the Development of Soviet Music (W. W. Norton, 1970), 233-57; Boris Schwarz, Music and Musical Life in Soviet Russia, 1917-1981, enl. ed. (Bloomington: Indiana University Press, 1983). In addition, even Ivanovskiy and Georgiy Munblit, one of the screenwriters, only devote a handful of pages to the film in their reminiscences. See Ivanovskiy, Vospominaniya kinorezhissera, 242-45; G[eorgiy] Munblit, Rasskazï o pisatelyakh [Stories about Writers: A Short Narrative] (Moscow: Sovetskiy pisatel', 1968), 135-37.

${ }^{66}$ Ol'ga Berggol'ts, Dnevnïe zvezdï [Daytime Stars] (Leningrad: Lenizdat, 1964), 176-77.
} 


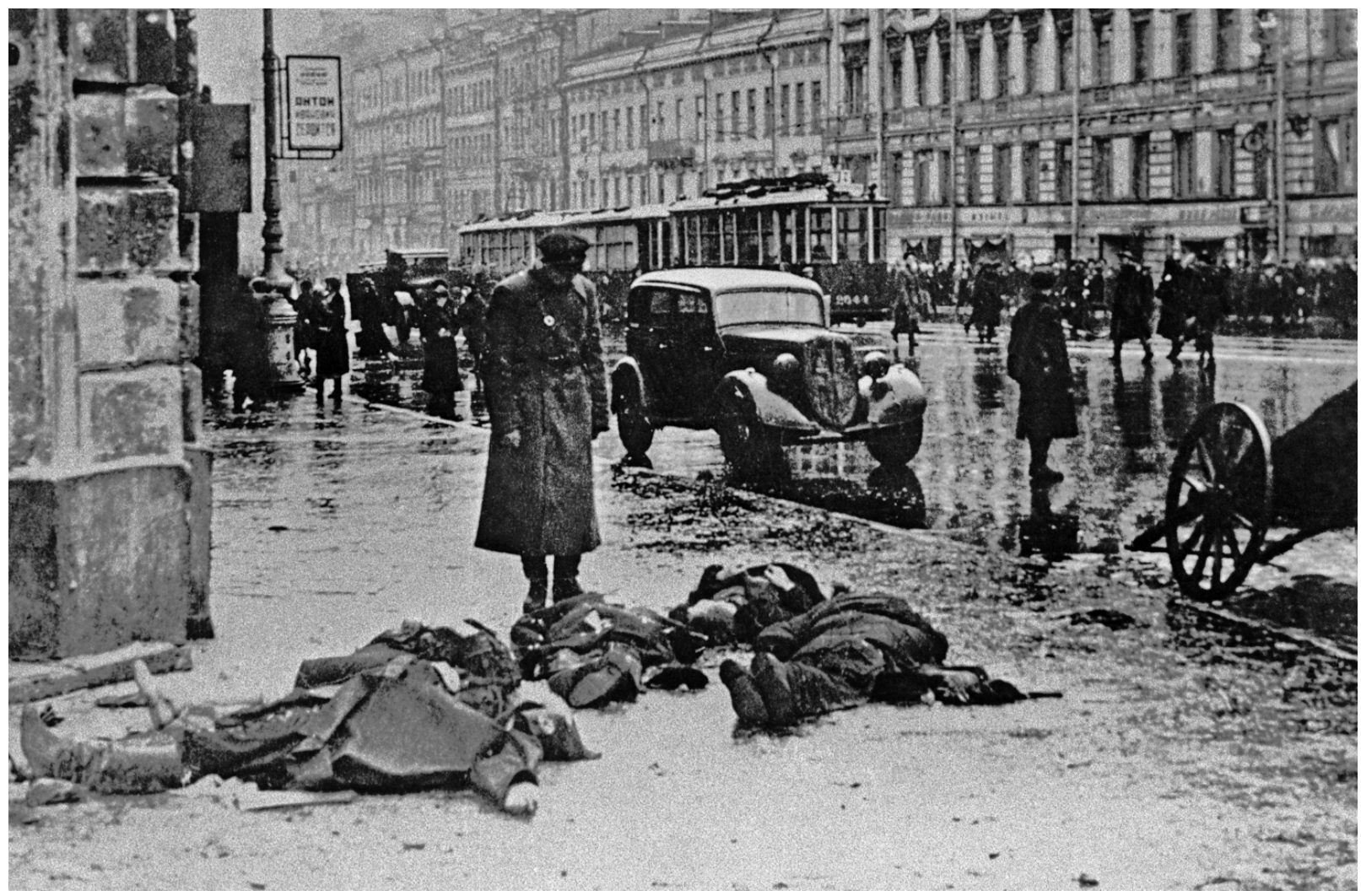

Figure 1: The Siege of Leningrad, 1942 (AIS Poster Hangs on Lamppost)

Source: TASS/Getty Images

Clearly, the continued presence of these posters had a traumatic effect on Berggol'ts and, presumably, other citizens as well. These reminders of popular entertainment and escape-of normalcyfloated obliviously above the dreadful reality transpiring below, the title of the film providing an eerie anthropomorphized commentary on the events. Thus, because of the unfortunate timing of its release, it is understandable that memory of and interest in AIS faded (particularly for citizens of Leningrad) ${ }^{67}$

Nevertheless, as a document of its time, AIS reveals a great deal about perceptions of Soviet musical style, aesthetics, and value. Specifically, it reflects one aspect of the contemporary musical politics of socialist realism, namely the desire to equalize, if not blend, serious and light music. And Ivanovsky and Kabalevsky achieve this, in part, by creating a heightened sense of musical realism made possible by avoiding the grandiose audio-visual hierarchy reversals of the musical numbers so common in earlier Soviet musical comedies. Instead, the music is entirely diegetic, whether that of the old German masters revered still in Soviet concert halls in the late 1930s or the new music by Mukhin, actually composed by a real Soviet composer (i.e., Kabalevsky) who himself championed the blending of high and low. But this more realistic musical approach includes also a darker side: the mocking and censure of the formalist Kerosinov. Though his character is of course a caricature and musicians had, in fact, "got[ten] off lightly" during the Great Terror in the mid-1930s, the public shaming of a composer interested in art for art's sake was nevertheless an ominous sign, particularly given the democratic message regarding serious and light music. $^{68}$ Despite Mukhin's plea to the contrary, "music," it turns out, is not "music." Given the very real

\footnotetext{
${ }^{67}$ Anecdotal accounts communicated to me by several people who lived in the Soviet Union, however, indicate that the film experienced a renaissance of sorts in the later Soviet period due to screenings on television.

${ }^{68}$ Caroline Brooke, "Soviet Musicians and the Great Terror," Europe-Asia Studies 54, no. 3 (May 2002): 410,
} 
consequences for composers that such attitudes led to during Zhdanov's post-war anti-formalist campaign, it is this, perhaps, that we wish Anton Ivanovich had gotten upset about instead.

\section{Bibliography}

Abraham, Gerald. “Dmitry Kabalevsky.” In Eight Soviet Composers, 70-78. London: Oxford University Press, 1943.

Abramovskiy, G[eorgiy]. D. Kabalevskiy. Moscow: Sovetskiy kompozitor, 1960.

Aleksandrov, G. F. "Dokladnaya zapiska nachal'nika upravleniya propagandï i agitatsii TsK VKP(b) G. F. Aleksandrova sekretaryam TsK VKP(b) A. A. Andreyevu, A. A. Zhdanovu, G. M. Malenkovu 'O plane proizvodstva khudozhestvennïkh fil'mov na 1941 god' (31 Marta 1941 g.) [Memorandum of the Head of the Department of Propaganda and Agitation of the Central Committee of the AllUnion Communist Party (Bolsheviks) G. F. Aleksandrov to the Secretaries of the Central Committee of the All-Union Communist Party (Bolsheviks) A. A. Andreyev, A. A. Zhdanov, G. M. Malenkov 'About the Production Plan for Feature Films in the year 1941' (31 March 1941)].” In Kino na voyne: Dokumenti i svidetel'stva [Cinema During the War: Documents and Records], edited by V. I. Fomin, 24-28. Moscow: Materik, 2005.

—. "Sprakva nachal'nika upravleniya propagandi i agitatsii TsK VKP(b) G. F. Aleksandrova sekretaryu TsK VKP(b) A.S. Shcherbakovu 'Ob otpravke za granitsu sovetskikh kinofil'mov' (Ne pozdneye 18 Marta 1942 g.) [Notification of the Head of the Department of Propaganda and Agitation of the Central Committee of the All-Union Communist Party (Bolsheviks) G. F. Aleksandrov to the Secretary of the Central Committee of the All-Union Communist Party (Bolsheviks) A.S. Shcherbakov 'About the Foreign Distribution of Soviet Films' (Not later than 18 March 1942)].” In Kino na voyne: Dokumenti i svidetel'stva [Cinema During the War: Documents and Records], edited by V. I. Fomin, 558-60. Moscow: Materik, 2005.

Altman, Rick. The American Film Musical. Bloomington: Indiana University Press, 1987.

Anderson, Trudy. "Why Stalinist Musicals?” Discourse 17, no. 3 (1995): 38-48.

Anon. “Anton Ivanïch Serditsya [Anton Ivanovich Is Upset].” Kadr, October 26, 1940.

"[Anton Ivanovich serditsya] [Anton Ivanovich Is Upset].” In Izbrannïye stsenarii sovetskogo kino [Selected Scripts from Soviet Cinema], 3:473-517. Moscow: Goskinoizdat, 1949.

Berggol'ts, Ol'ga. Dnevnïe zvezdï [Daytime Stars]. Leningrad: Lenizdat, 1964.

Brooke, Caroline. "Soviet Musicians and the Great Terror." Europe-Asia Studies 54, no. 3 (May 2002): 397413. https://doi.org/10.1080/09668130220129533.

https://doi.org/10.1080/09668130220129533. 
Clark, Katerina. Moscow, the Fourth Rome: Stalinism, Cosmopolitanism, and the Evolution of Soviet Culture, 19311941. Cambridge, MA: Harvard University Press, 2011.

https://doi.org/10.4159/harvard.9780674062894.

Danilevich, L[ev Vasil'yevich]. Tvorchestvo D. B. Kabalevskogo [The Oeuvre of D. B. Kabalevskiy]. Moscow: Sovetskiy kompozitor, 1963.

Daragan, Dina. Kinomuzika D. Kabalevskogo [The Film Music of D. Kabalevskiy]. Moscow: Muzïka, 1965.

Dobrenko, Evgeny. "The Singing Masses and the Laughing State in the Musical Comedy of the Stalinist 1930s: The Problem of 'Popular Spirit' in Socialist Realist Aesthetics." In Reflective Laughter: Aspects of Humour in Russian Culture, edited by Lesley Milne, 131-45. London: Anthem Press, 2004.

Egorova, Tatiana K. Soviet Film Music: An Historical Survey. Translated by Tatiana A. Ganf and Natalia A. Egunova. Amsterdam: Overseas Publishers Association, 1997.

Fairclough, Pauline. Classics for the Masses: Shaping Soviet Musical Identity under Lenin and Stalin. New Haven: Yale University Press, 2016. https://doi.org/10.12987/yale/9780300217193.001.0001.

Frolova-Walker, Marina. Russian Music and Nationalism: From Glinka to Stalin. New Haven: Yale University Press, 2007.

—. "Stalin and the Art of Boredom." Twentieth-Century Music 1, no. 1 (2004): 101-24. https://doi.org/10.1017/S1478572204000088.

_. Stalin's Music Prize: Soviet Culture and Politics. New Haven: Yale University Press, 2016. https://doi.org/10.12987/yale/9780300208849.001.0001.

Glezer, R[aisa Vladimirovna]. Dmitriy Borisovich Kabalevskiy. Moscow: Sovetskiy kompozitor, 1969.

Grosheva, Ye[lena]. D. Kabalevskiy. Moscow: Muzïkal'nïy fond SSSR, 1956.

Hakobian, Levon. Music of the Soviet Age, 1917-1987. Stockholm: Melos Music Literature, 1998.

Ivanovskiy, Aleksandr Viktorovich. Vospominaniya kinorezhissera [Memoirs of a Film Director]. Moscow: Iskusstvo, 1967.

Kabalevskiy, Dm[itriy]. Pro tryokh kitov i pro mnogoye drugoye: Knizhka o muzike [About the Three Whales and Many Other Things: A Book on Music]. Moscow: Detskaya literatura, 1972.

Kabalevskiy, Dmitriy. Vesna poyot (operetta v 3 aktakh) [The Spring Sings (operetta in 3 acts)], libretto by Ts. Solodar", [piano vocal score]. Moscow: Sovetskiy kompozitor, 1959.

Kenez, Peter. Cinema and Soviet Society from the Revolution to the Death of Stalin. New ed. London: I.B. Tauris, 2001.

Krebs, S. D. "Dmitri Kabalevsky." In Soviet Composers and the Development of Soviet Music, 233-57. W. W. Norton, 1970.

Kupfer, Peter. "'Our Soviet Americanism': Jolly Fellows, Music, and Early Soviet Cultural Ideology.” Twentieth-Century Music 13, no. 2 (September 2016): 201-32. https://doi.org/10.1017/S1478572216000049. 
_ . "Volga-Volga: 'The Story of a Song,' Vernacular Modernism, and the Realization of Soviet Music." The Journal of Musicology 30, no. 4 (2013): 530-76. https://doi.org/10.1525/jm.2013.30.4.530.

Macheret, Aleksandr Venyaminovich, and Nina Alekseyevna Glagoleva. Sovetskiye khudozhestvennïye fil'mï: annotirovannïy katalog [Soviet Feature Films: An Annotated Catalog]. Vol. 2. Moscow: Iskusstvo, 1961.

Mikkonen, Simo. Music and Power in the Soviet 1930s: A History of Composers' Bureaucracy. Lewiston, NY: Edwin Mellen Press, 2009.

Munblit, G[eorgiy]. Rasskazï o pisatelyakh : malen'kaya povest' [Stories about Writers: A Short Narrative]. Moscow: Sovetskiy pisatel', 1968.

Nelson, Amy. "The Struggle for Proletarian Music: RAPM and the Cultural Revolution.” Slavic Review 59, no. 1 (2000): 101-32. https://doi.org/10.2307/2696906.

Nisnevich, Anna. "Listening to Muzykal'naia istoriia (1940)." In Sound, Speech, Music in Soviet and Post-Soviet Cinema, edited by Lilya Kaganovsky and Masha Salazkina, 193-211. Bloomington: Indiana University Press, 2014.

Pozhidayev, G[ennadiy Alekseyevich]. Dmitriy Kabalevskiy. Kiev: Muzichna Ukraïna, 1984.

Raku, Marina. Muzikal'naya klassika v mifotvorchestve sovetskoy epokhi [Musical Classicism in the Mythology of the Soviet Epoch]. Moscow: Novoye literaturnoye obozrenie, 2014. Google Play e-book, https://play.google.com/store/books/details?id=LcTSBgAAQBAJ\&hl=en (accessed June 1, 2018).

Roshal', Grigoriy. "Radostnaya kinosyuita [Joyful Film Suite].” In Dmitriy Kabalevskiy: Tvorcheskie vstrechi, ocherki, pis'ma [Dmitry Kabalevsky: Creative Encounters, Essays, Letters], 15-27. Moscow: Sovetskiy kompozitor, 1974.

Salys, Rimgaila. The Musical Comedy Films of Grigorii Aleksandrov: Laughing Matters. Chicago: Intellect Ltd, 2009.

Schwarz, Boris. Music and Musical Life in Soviet Russia, 1917-1981. Enl. ed. Bloomington: Indiana University Press, 1983.

Starr, S. Frederick. Red and Hot: The Fate of Jazz in the Soviet Union, 1917-1991. 2nd ed. New York: Limelight, 1994.

Taruskin, Richard. "Two Serendipities: Keynoting a Conference, 'Music and Power." In Russian Music at Home and Abroad: New Essays, 303-31. Berkeley: University of California Press, 2016. https://doi.org/10.1525/jm.2016.33.3.401.

Taylor, Richard. "But Eastward, Look, the Land Is Brighter: Towards a Topography of Utopia in the Stalinist Musical.” In 100 Years of European Cinema: Entertainment Or Ideology?, edited by Diana Holmes and Alison Smith, 11-26. Manchester: Manchester University Press, 2000.

_. "Ideology as Mass Entertainment: Boris Shumyatsky and Soviet Cinema of the 1930s." In Inside the Film Factory: New Approaches to Russian and Soviet Cinema, edited by Richard Taylor and Ian Christie, 193-216. New York: Routledge, 1991. 
. "Red Stars, Positive Heroes, and Personality Cults." In Stalinism and Soviet Cinema, edited by Derek Spring and Richard Taylor, 69-89. New York: Routledge, 1993.

—. "Singing on the Steppes for Stalin: Ivan Pyr'ev and the Kolkhoz Musical in Soviet Cinema." Slavic Review 58, no. 1 (1999): 143-59. https://doi.org/10.2307/2672993.

- "The Illusion of Happiness and the Happiness of Illusion: Grigorii Aleksandrov's The Circus." The Slavonic and East European Review 74, no. 4 (1996): 601-20.

Toropova, Anna. "If We Cannot Laugh like That, Then How Can We Laugh?': The 'Problem' of Stalinist Film Comedy." Studies in Russian and Soviet Cinema 5, no. 3 (2011): 335-51. https://doi.org/10.1386/srsc.5.3.335_1.

Yankovskiy, M[oisey Osipovich]. "Pochemu serditsya Anton Ivanovich? [Why is Anton Ivanovich Upset?].” Kino, January 24, 1941.

Yurenev, Rostislav Nikolayevich. Sovetskaya kinokomediya [Soviet Comedy Cinema]. Moscow: Nauka, 1964.

Zhdanov, A. A. "'Uncorrected Transcript of Introductory Remarks by TsK VKP(b) Secretary A. A. Zhdanov at a Meeting of Cinematographers at the TsK VKP(b),' 14 May 1941, RGASPI. f. 77, Op. 1, Ll. 1a-7." In Soviet Culture and Power: A History in Documents, 1917-1953, edited by Katerina Clark and Evgeny Dobrenko, 273-75. New Haven: Yale University Press, 2007. 